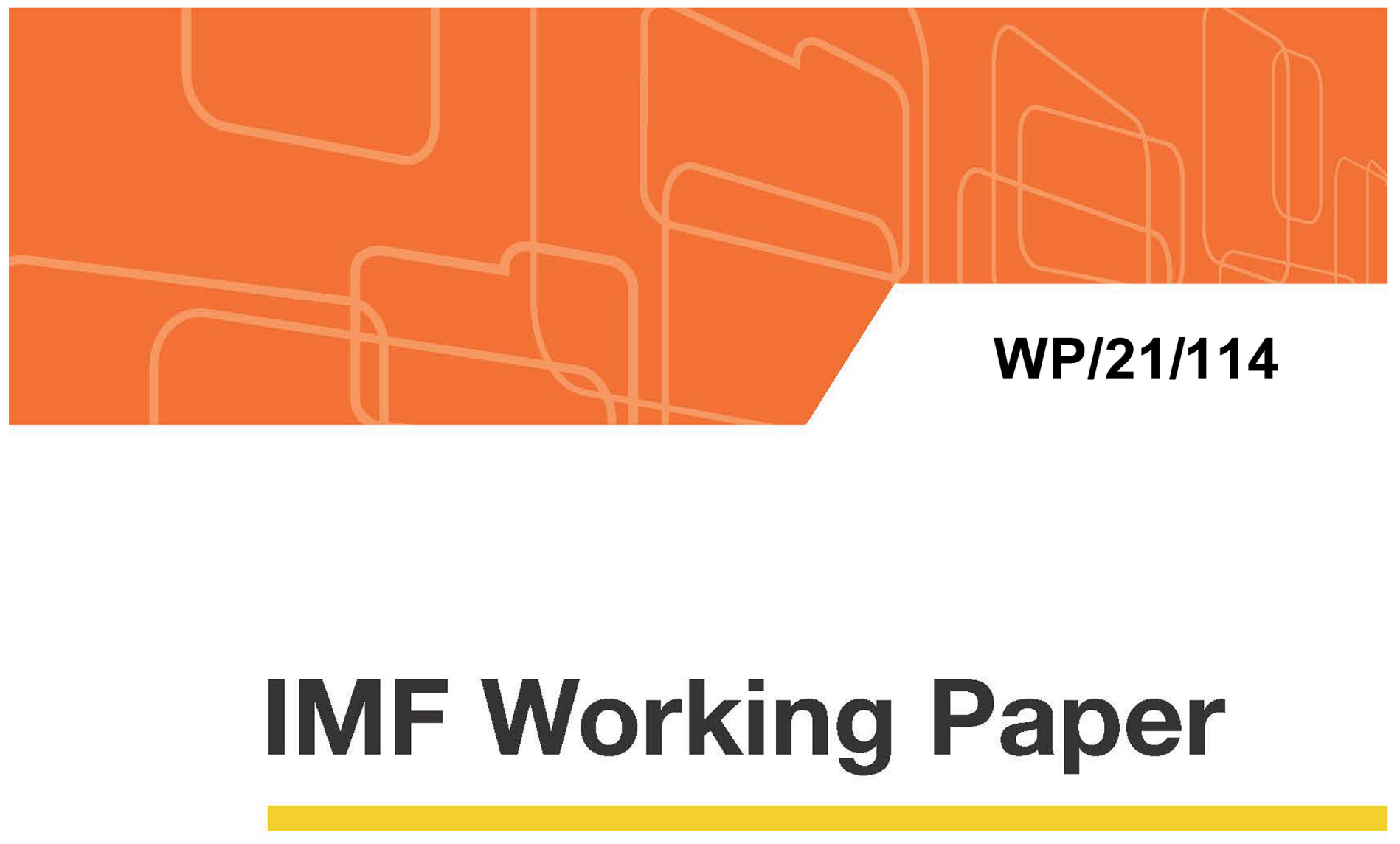

\title{
Can Fintech Foster Competition in the Banking System in Latin America and the Caribbean?
}

by Suchanan Tambunlertchai, Pablo Bejar, Kotaro Ishi, Takuji Komatsuzaki, Ippei Shibata, and Jasmin Sin

IMF Working Papers describe research in progress by the author(s) and are published to elicit comments and to encourage debate. The views expressed in IMF Working Papers are those of the author(s) and do not necessarily represent the views of the IMF, its Executive Board, or IMF management. 


\title{
IMF Working Paper
}

\section{Can Fintech Foster Competition in the Banking System in Latin America and the Caribbean?}

\author{
Prepared by Suchanan Tambunlertchai, Pablo Bejar, Kotaro Ishi, \\ Takuji Komatsuzaki, Ippei Shibata, and Jasmin $\operatorname{Sin}^{1}$
}

Authorized for distribution by Patricia Alonso-Gamo

April 2021

\begin{abstract}
IMF Working Papers describe research in progress by the author(s) and are published to elicit comments and to encourage debate. The views expressed in IMF Working Papers are those of the author(s) and do not necessarily represent the views of the IMF, its Executive Board, or IMF management.
\end{abstract}

\begin{abstract}
This paper revisits the competitive environment of the banking system in Latin America and the Caribbean (LAC) and investigates the early impact of fintech development in the region thus far. Against the backdrop of high net interest margins (NIMs) and limited financial depth in the region, panel regressions broadly confirm results of existing literature on the association of NIMs with the changes in the financial sector structure, including market concentration, administrative costs, and foreign banks, although differences between domestic and foreign banks narrowed after the 2008-09 Global Financial Crisis. Difference-in-difference regressions and case studies on Brazil and Mexico suggest that fintech is associated with a reduction in NIMs and defensive

\footnotetext{
${ }^{1}$ Prepared by Western Hemisphere Department Fintech working group, led by S. Pelin Berkmen and under the guida nce of Patricia Alonso-Gamo. We are gra teful for comments by Alejandro Werner, Sole MartinezPeria, Deniz Igan, Andrea Presbitero, Nicola Pierri, Kevin Wiseman, Federico Grinberg and WHD seminar participants. The cases studies incorporate interviews with market participants and country authorities, including Banco de Mexico, Comisión Nacional Bancaria y de Va lores (CNBV) of Mexico, the Ministry of Finance of Mexico, and Banco Centraldo Brasil. We are gra teful for their time and detailed comments. All remaining errors a re those of authors.
} 
responses by incumbent banks that benefit consumers. The case studies also shed light on regulatory approaches and prudential considerations in fostering financial innovation and banking sector competition.

JEL Classification Numbers: D4, G21, L11, N26, O31, O38

Keywords: Banking, Competition, Fintech, Latin America and the Caribbean

Author’s E-Mail Address: STambunlertchai@imf.org, PBejarVera@imf.org, KIshi@imf.org TKomatsuzaki@imf.org, IShibata@imf.org, JSin@imf.org 


\section{INTRODUCTION}

The financial sector in Latin America and the Caribbean (LAC) has undergone large structural changes. Financial liberalization in the 1990s was followed by a wave of foreign acquisition of local banks that drove consolidation in the sector (Cardim de Carvalho et. al, 2012). Foreign presence in the region waxed and waned through financial and sovereign debt crises, with more sustained exits of North American and European banks following the global financial crisis in the late $2000 \mathrm{~s}$, followed by entries of regional institutions. In more recent years, another structural change has begun to take place within the region. The use of financial technology-or "fintech"-in banking services has emerged and grown at a rapid pace (Berkmen et al., 2019). According to the Inter-American Development Bank, the number of fintech companies in Latin America grew 66 percent (from 703 to 1166) between 2017 and 2018.

The trend in Latin America mirrors that taking place across the world where information technology, the internet, and mobile services are changing the way consumers and businesses access and manage their finances. In particular, fintech companies have been adept at unbundling traditional banking services, offering targeted solutions for existing constraints or inefficiencies including reaching out to unbanked segments of the population. The rise of fintech has disrupted the banking sector, challenging the way banks operate. This has already forced incumbent banks to increase their efficiency and invest more in innovation. Whether fintech can or has threatened the incumbent banks' market shares and profit margins, thereby affecting competition in the banking sector, is an open question.

Different types of fintech entries imply different effects on banking sector competition. Fresh entries may not threaten incumbent banks if they target a parallel market with limited banking presence. In other instances, new fintech entrants directly compete with banks-peer-to-peer lending platforms, for example, entirely bypass banks in the intermediation process. Findings by Mansilla-Fernandez (2017) that fintech investments have been higher in countries with less competitive banking sectors (i.e., those with greater concentration and higher net interest margins) suggest that fintech is likely to foster more competition in financial services. The observed increase in banks' IT investment as well as direct investment in fintech startups in recent years also appear to confirm that banks see fintech firms as a potential threat and the use of fintech as a way to maintain market relevance going forward. Such investments by banks could enhance competition between the incumbents and the newcomers, as well as competition among the incumbents, compelling all players to vie for market share by offering new products, improving the customer experience, and passing on cost savings to customers.

An important force shaping the relationship between incumbent banks and fintech is financial regulation. While financial authorities have generally welcomed fintech as an opportunity to improve banking sector competition, efficiency, and financial inclusion, the regulatory response to fintech has taken different approaches. If the eventual regulatory environment provides for a level playing field between fintech firms and traditional banks, the banking sector could see 
more competition and lower concentration. If, however, incumbent banks are able to deploy their vast resources to take over fintech companies or outstrip fintech firms in innovations, we may find that fintech has little impact on banks' concentration even if financial inclusion and efficiency are improved.

This paper revisits the competitive environment of the banking system in LAC and investigates the early impact of fintech development in the region thus far, combining empirical and casestudy approaches. With fintech expansion still ongoing, the full picture of its impact on the banking sector is just starting to emerge. This is especially true in LAC where fintech development is in the early stages with limited data availability. And because fintech both complements and challenges traditional banks, its impact on banking sector competition will be difficult to assess. While the paper cannot provide a definitive answer, it aims to shed light on the early evidence on how fintech has affected banking sector competition in LAC.

The empirical part starts with documenting stylized facts on the competitive landscape of the banking sector in LAC, highlighting high net interest margins (NIMs) and limited financial depth in the LAC in comparison with those in the other regions. Then we re-examine how the changes in the financial sector structure (such as concentration, foreign bank entries, and M\&A) has been associated with banking sector competition in the region by panel regressions using bank-level data. Although this approach does not directly address a question about how fintech could affect banking sector competitiveness, we can infer from the past experience if an increase in competition with fintech companies could potentially affect banks' behavior. Finally, we extend the panel regressions into a diff-in-diff setting to illustrate the association of fintech emergence with changes in the competitive environment.

Our empirical results broadly confirm the results of existing literature on the association of NIMs with the changes in the financial sector structure, including market concentration, administrative costs, and foreign banks, although the paper finds that differences between domestic and foreign banks narrowed after the 2008-09 Global Financial Crisis (GFC). Difference-in-difference regressions suggest that fintech is associated with a reduction in NIMs.

The case study focuses on the fintech development in Brazil and Mexico, the two most developed fintech markets in the region. While there are many country-specific differences, in both cases we observe defensive responses by incumbent banks such as investing in innovation, improving their efficiency and customer service and partnership with fintech, and encouraging signs that fees are declining on the payment side. We also discuss the financial regulators' difficult balancing act in promoting fintech, protecting consumers, and mitigating potential risks to the financial sector.

This paper follows up Berkmen and others (2019), a broad stocktaking work of the fintech in Latin America and the Caribbean, with a focus on the competition effect of the fintech. It also draws on Cambridge Centre for Alternative Finance (2018a, 2018b, 2020) and Inter-American 
Development Bank $(2017,2018)$. Building these studies whose focus are on documenting stylized facts, we take a first step in quantitative analysis of the fintech in LAC banking sector. We adopt the empirical framework of Martinez Peria and Mody (2004) for this purpose and update their analysis on the association of NIM with changes in financial sector structure in LAC.

Note that the analytical focus of this paper is for pre-pandemic periods. The ongoing COVID-19 crisis may have been encouraging the development of the Fintech sector, because digital financial services allow for social distancing and allow many households and firms to rapidly access online payments and financing (Agur and others, 2020). More specifically, technology helped channel funds to small and medium-sized enterprises in serious need of financial relief (Cantú and Ulloa, 2020). Due the lack of the data, however, this paper does not address the implication of the COVID-19 crisis on fintech developments in LAC.

The rest of the paper is organized as follows. Section I documents stylized facts regarding the competitive environment in the LAC banking sector. Section II first introduces panel regressions and reports on the determinants of the banking sector in general, and then extend the regressions to include diff-in-diff terms, in order to highlight the effects of the fintech. Section III presents case studies. Section IV offers concluding thoughts.

\section{COMPETITIVE LANDSCAPE OF THE BANKING SECTOR IN LAC}

The banking sector in LAC is characterized by limited financial depth and high interest spreads. The level of financial intermediation in the region lags behind advanced economies and emerging markets in Asia and Europe (Figure 1). The limited financial depth may be related to the cost of financial intermediation in the region. Countries in LAC are among those with the highest net interest margins (NIMs) in the world (Figure 2). ${ }^{2}$ As Figure 2 shows, the high NIMs in LAC have persisted over an extended period of time even as other regions have seen a decline in these margins. This has raised questions about the competitiveness of the banking sector in the LAC region as competition should in principle compress NIMs as banks compete for loans and deposits by offering, respectively, lower lending rates and higher deposit rates.

\footnotetext{
${ }^{2}$ The net interest margin (NIM) measures the difference between the interesta bank charges for its loans and the interest it pays on deposits.
} 
Figure 1. Credit to Private Sector in 2018 (Percent of GDP)

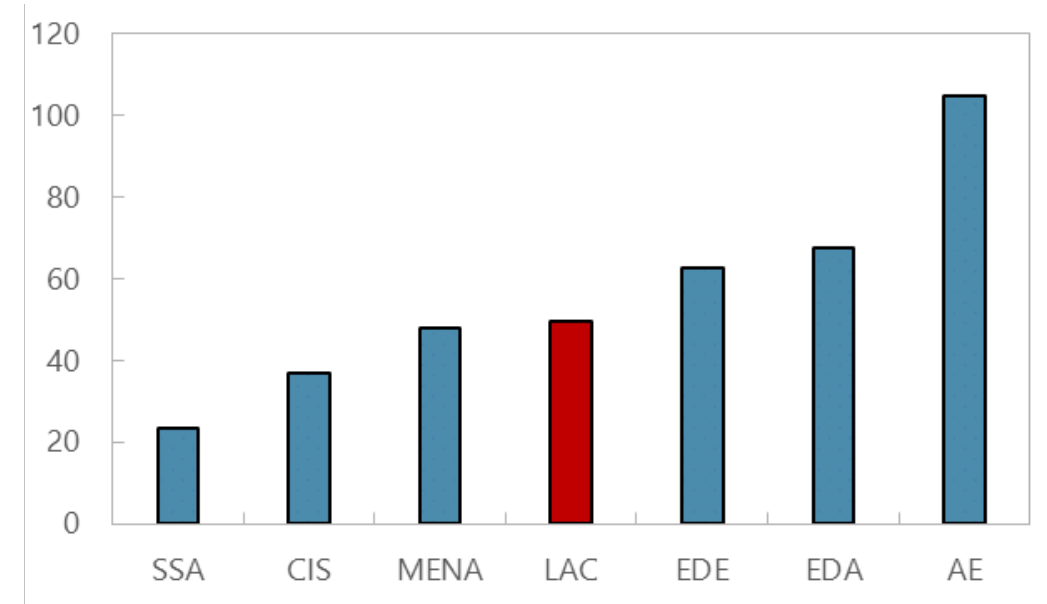

Figure 2. Average Net Interest Margins (percent of total assets)

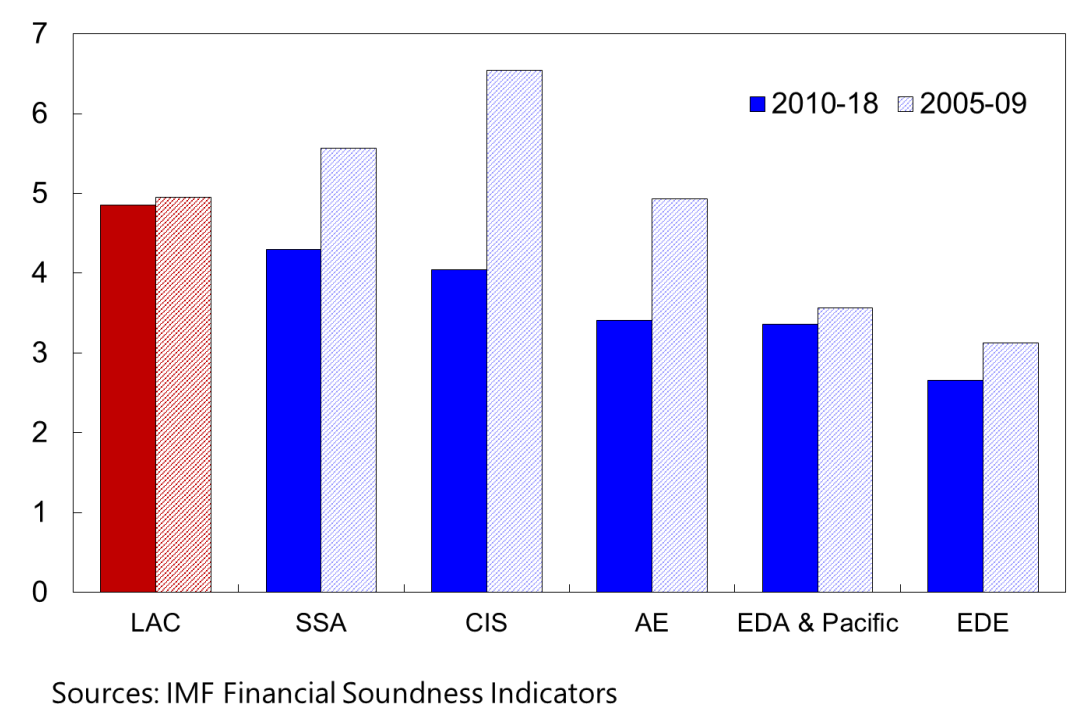

Among the LAC countries for which we have data on NIMs, there is considerable cross-country variation (Figure 3). Despite the differing levels of NIMs, however, countries share some common patterns when segmenting NIMs by the type of bank. In Argentina, Brazil, Chile, and Peru, private domestic banks have higher NIMs than private foreign-owned banks. The reverse is true in Bolivia, Colombia, and Mexico, where NIMs for foreign banks are slightly higher than those for domestic banks. And with the exception of Uruguay where public banks appear to have higher NIMs than other bank types, public banks in other countries generally have substantively 
lower NIMs than the private domestic banks (Figure 4). In Mexico and Colombia, the average NIMs for public banks are less than half those of private banks. ${ }^{3}$

\section{Figure 3. Interest Margins in LAC, 2010-19 (percent of total assets)}

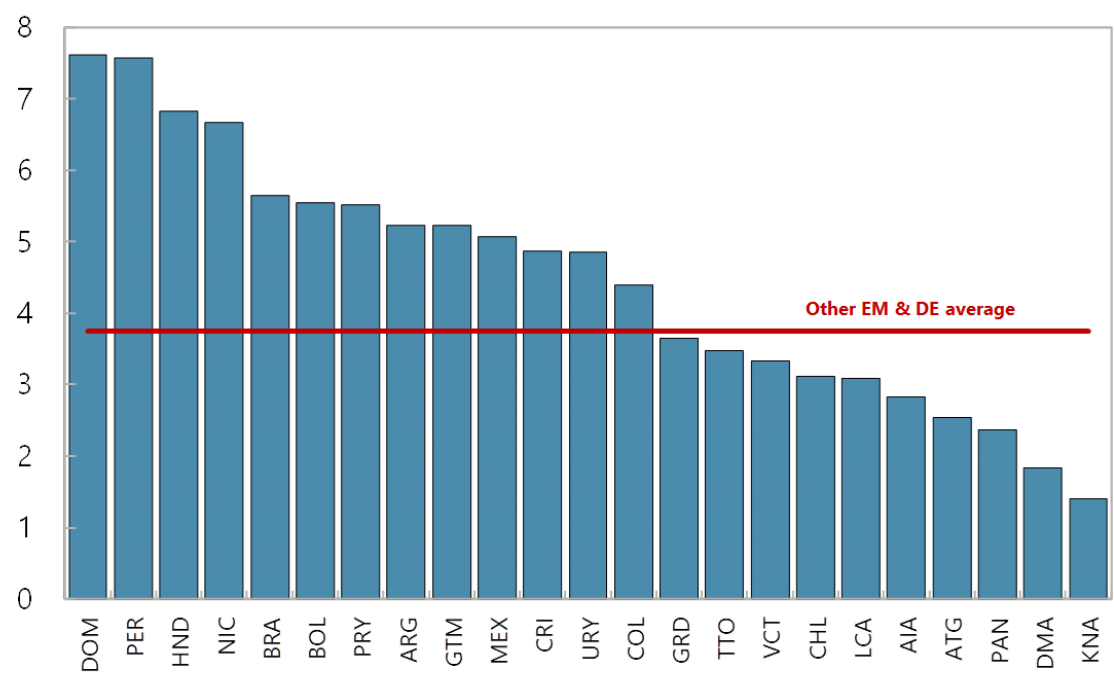

Sources: IMF Financial Soundness Indicators

Figure 4. Net Interest Margins in LAC Banks

(Gross int. revenue + Dividend income - Total interest expense)/Avg. assets

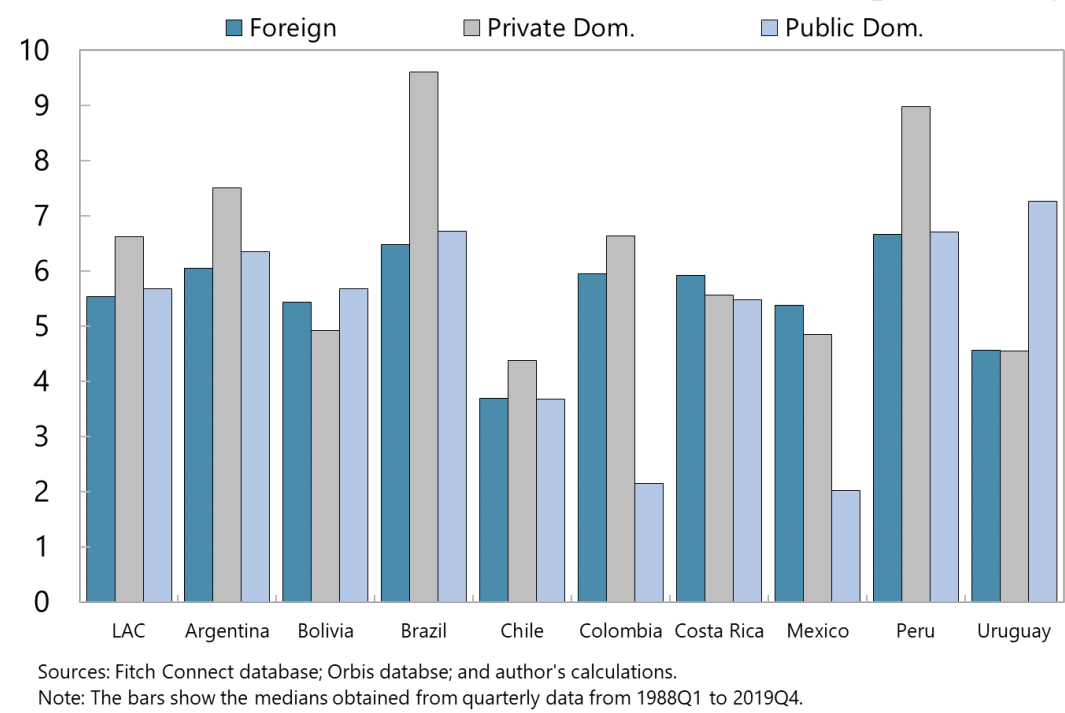

The literature argues that high NIMs reflect some combination of low competition and high operating costs (e.g., Ho and Saunders, 1981; Saunders and Schumacher, 2000; Williams, 2007). The high operating costs may stem from premia for greater underlying macroeconomic risks

\footnotetext{
${ }^{3}$ In addition to NIMs, we consider banks' non-interest income which includes fees (e.g., monthly fee, late fee, overdraft fee, loa n origination fee), and revenues from sale of products or services such a sinsurance, brokerage, and fina ncial planning. Among LAC countries, non-interest incomes are significant for Argentina (at nearly 4 percentof a verage assets), followed by Colombia and Uruguay (both at around 2 percent of average a ssets).
} 
(Beck et al., 2003; Maudos and Solis, 2009), tighter regulatory requirements (Saunders and Schumacher, 2000; Gelos, 2006), or institutional setting including property rights protection (Demirgüç-Kunt, Laeven, and Levine, 2004). Cardim de Carvalho et. al (2012) show that in the late 1990s to early 2000s, regions with the highest NIMs (as shown in Figure 2) - Sub-Saharan Africa, Eastern Europe and Central Asia (which includes CIS), and LAC - were also those with the highest overhead costs for banks. In the LAC context, high NIMs have been attributed to factors such as high interest rate levels, stringent reserve requirements, and high operating costs due to bank inefficiencies (Gelos, 2006; Cardim de Carvalho et. al, 2012).

It is important to acknowledge that structurally high costs may or may not reflect low competition. High costs due to high tax es or more restrictive labor and banking sector regulations are different from those due to inefficiency, but both would be reflected in higher NIMs. The former may lead to higher NIMs as banks try to maintain profits after incurring noninterest costs. The latter, however, would indicate low competition as competitive pressure would generally ensure exits of the inefficient firms.

To account for both interest and non-interest costs, we consider the Lerner index which reflects the "markup" or the difference between output price and input cost. The ability of a firm to maintain a markup is often interpreted as market power that stems from a lack of competitive pressure. Higher values of the Lerner index are associated with greater market power. ${ }^{4}$ Figure 5 shows the average Lerner index values for banks in LAC countries for which data are available. Notably, Brazilian and Uruguayan banks which are among those with the highest NIMs in the region appear to have lower markups. This suggests that the high NIMs may be driven by high costs which, as noted above, could be due to low competition or high regulatory costs (e.g., macroprudential requirements, labor laws) or both. In contrast, markups for Colombian banks are high even despite more moderate NIMs. Peruvian banks have both high markups and high NIMs which suggest low competition in the banking sector.

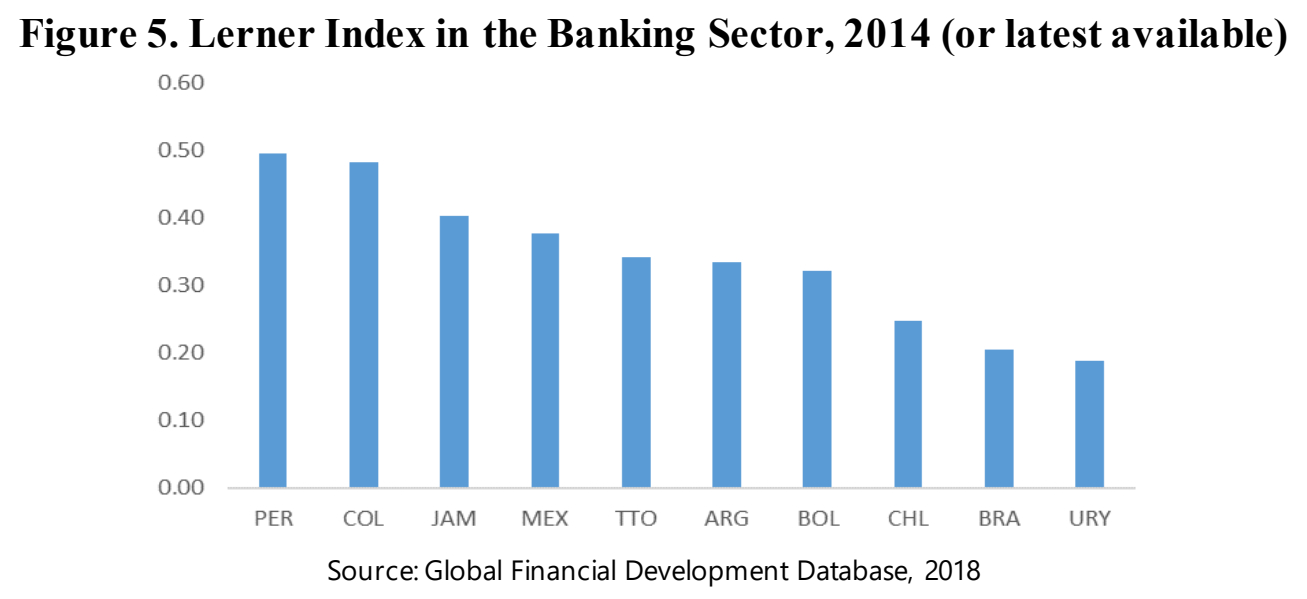

\footnotetext{
${ }^{4}$ Strictly spea king, the mapping between the Lerner index and market power holds only under certain conditions. See Shaffer and Spierdijk(2020).
} 
High NIMs have also been associated with greater levels of concentration in the banking sector (see, for example, Maudos and Fernández de Guevara, 2004; Maudos and Solís 2009; Saunders and Schumacher 2000; and Williams 2007). However, Beck et al. (2003) show that the positive association between concentration and bank margins disappears when controlling for institutional developments. Claessens and Laeven (2004), who do not find links between market structure and banks' spreads, argue that concentration variables typically used may not be good proxies for the degree of competition in the banking sector.

Figure 6 shows the 3-bank concentration measure for each region. The measure shows a generally high level of concentration in the banking sector across the world, with assets of the top three banks across all regions on average making up more than half of the total banking sector assets. Emerging and Developing Asia (EDA) has the lowest average 3-bank concentration at 51.6 percent while AEs, which has the lowest NIMs, has the highest 3-bank concentration at 68.4 percent. ${ }^{5} \mathrm{LAC}$ as a region stands at 63.5 percent, slightly above the median. Compared to the previous decade, the level of banking concentration went down across all regions. As with NIMs, LAC saw the smallest improvement in this indicator. And once again, there is considerable heterogeneity among countries in the region.

Figure 6. Assets of the 3 Largest Banks (percent of commercial banks' assets)
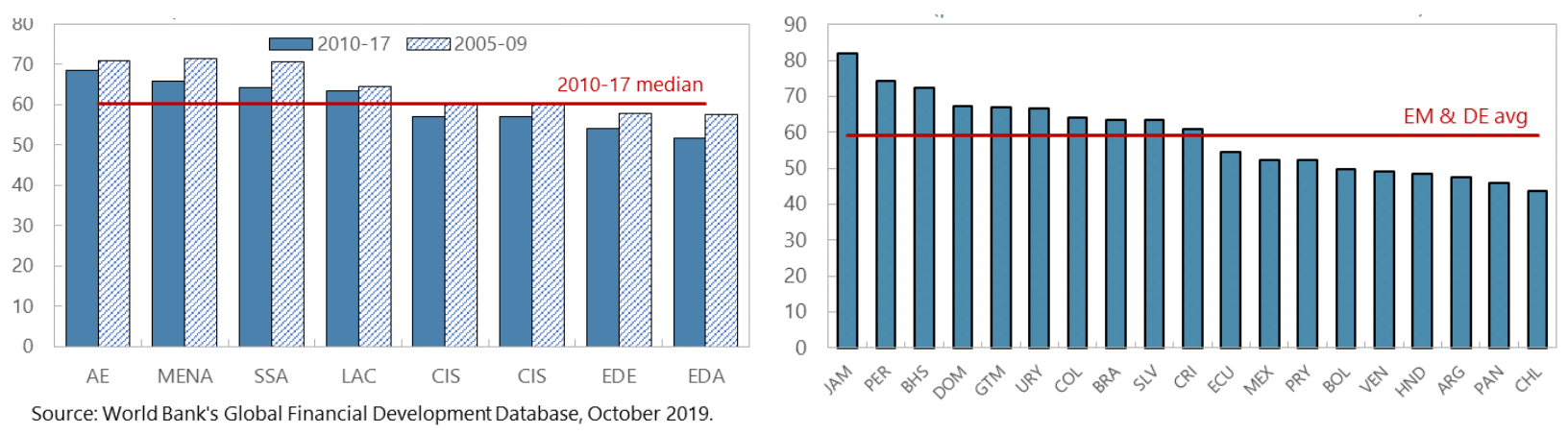

Ultimately what matters for competition is market contestability - the possibility of new market entrants taking away incumbents' market shares. To the extent that market concentration arises from barriers to entry or confers market power on incumbents, concentration would reflect anticompetitive forces that lead to higher prices and lower quantities. In the banking sector context, this would be reflected in high NIMs and less financial depth (or more limited financial products), both of which are true for LAC. The evidence presented in this section thus suggests that there may be scope to improve banking sector competition in the region, particularly in countries where persistently high NIMs have been accompanied by high concentration.

\footnotetext{
${ }^{5}$ The high concentration in the banking sector may reflect to a nextent thenature of the banking sector, where concentration has been associated with grea ter banking sector sta bility a s la rger banks a re better placed to weather economic shocks.
} 
Because high NIMs are associated with financial sector inefficiencies and high costs of financial sector participation, creating conditions for a competitive banking sector to lower NIMs is an important policy goal that is intricately linked with financial deepening and financial inclusion. Past studies have shown that deregulation and foreign bank entries into the region coincided with lower spreads and improved cost efficiency in LAC banks (Yildirim and Philippatos, 2007; Cardim de Carvalho et. al, 2012). These previous experiences bode well for the current context where fintech firms' entries into the banking sector could threaten to take away incumbent banks' market share which could create competitive pressure that lead to more efficient outcomes. The next section empirically investigates this possibility by looking at the factors that influence NIMs in LAC, including the early fintech entries into the region.

\section{Determinants OF Net Interest MARgins In LAC}

Since Ho and Saunders (1981) developed their model for understanding bank spreads, the literature has seen many studies on the factors that influence banks' net interest margins. Examples of those that have focused on the LAC region include Brock and Rojas-Suarez (2000), Martinez Peria and Mody (2004), Gelos (2006), and Chortareas, Garza-Garcia, and Girardone (2011). In this section of the paper, we update the findings for LAC with the latest data that include the time period with nascent fintech activity in some countries. We first estimate an empirical model that closely follows Martinez Peria and Mody (2004), with a particular focus on the change in the financial sector structure (such as concentration, foreign bank entries, and M\&A). ${ }^{6}$ Although this approach does not directly address a question about how fintech could affect banking sector competitiveness, we can infer from the past experience if an increase in competition with fintech companies could potentially affect banks' behavior. Then, later adding fintech variables helps answer whether the impact of early fintech activities has already been empirically apparent.

\section{A. Data Description}

We use historical balance sheet data for 692 banks from 1988 to 2018 from the Fitch Connect Database for the following countries in LAC: Argentina, Bolivia, Brazil, Chile, Colombia, Costa Rica, Mexico, Peru, and Uruguay. Bank ownership and M\&A data are from the Orbis and Zyphyr databases as well as specific banking institutions' websites. Macroeconomic and macrofinancial data are gathered from the IMF's World Economic Outlook and the Financial Development Index databases.

\footnotetext{
${ }^{6}$ While this type of panel regressions is common in the literature, they do not necessarily establish a tight causality. For exa mple, we flag the en dogeneity possibility for market concentration, M\&A, a nd non-interest income variables below. More recently, the litera ture started to use more gra nula rcredit registry data to establish tighter causality rela tionships. This option is not a vailable to us, however, as credit registry data a ccess is typically limited to the authorities of the country.
} 
Foreign-owned banks in our sample are identified from those whose parent institutions have more than 50 percent foreign ownership. Banks whose ownership structure shift from domestically owned to foreign owned, but where the majority foreign owners are domiciled in offshore tax havens (e.g., Andorra, Bermuda, Bahamas, Virgin Islands, and in some cases Panama) are treated as domestic banks. Public banks in our sample are those with more than 50 percent ownership by the government or subnational institutions.

NIM is measured as the difference between gross interest income (interest on loans, other interests, and dividend income) and total interest expense (interest on deposits and other interest expense) as a percent of average assets. Table 1 provides the summary statistics of variables used.

\section{B. Baseline Regressions}

\section{Baseline specification}

Following Martinez Peria and Mody (2004), we specify a fixed effect panel regression model for the NIM with market structure and M\&A as key explanatory variables of our interest, and bankspecific factors and macroeconomic and financial environment as control variables. We also include additional variables to control for bank ownership structure and depth of the financial market. The regression model is as follows:

$$
Y_{i c t}=\alpha_{c}+\beta_{t}+\delta \text { Concentration }_{c t}+\mu M \& A_{c t}+\Gamma X_{i c t}+\Theta Z_{c t}+\eta \text { Access }_{c t}+\varepsilon_{i c t} \cdots
$$

where $Y_{i c t}$ is the NIM of bank $i$ in country $c$ in year $t ; X_{i c t}$ a vector of bank-specific characteristics; and $Z_{c t}$ macroeconomic conditions. The model controls for country and time fixed effects.

The concentration measure is the Herfindahl-Hirschmann Index (HHI), although we also test the model with the 3-bank concentration. ${ }^{7}$ The M\&A variable includes a dummy to indicate whether a bank in country $c$ in time period $t$ was acquired. We test alternate specifications using all M\&A (including both domestic and foreign) and only foreign M\&A.

Bank-specific explanatory variables, $X_{i c t}$, include liquid to total assets, equity to total assets, credit share in the banking sector, and non-performing loans (NPLs) to total assets. These variables capture the banks' risk profiles which can impact their NIMs. The bank-specific vector also includes net fee income, administrative costs to average assets, and the public and foreign ownership status.

\footnotetext{
${ }^{7} \mathrm{HHI}=\mathrm{s}_{1}{ }^{2}+\mathrm{s}_{2}{ }^{2}+\mathrm{s}_{3}{ }^{2}+\ldots+\mathrm{s}_{\mathrm{n}}{ }^{2}$, where $\mathrm{s}_{\mathrm{n}}$ is the market share of firm $\mathrm{n}$, is a mea sure ofmarket concentration. Higher HHI values indicate higher concentration. The 3 - and 5-bank concentrations are calculated from gross a ssets or gross loans.
} 
Macroeconomic variables in the model, $Z_{c t}$, include countries' credit to GDP, inflation, real GDP growth, short-term real interest rates, and sovereign EMBI spreads. Credit to GDP reflects the depth of the banking sector. Inflation is presumed to affect differently the interest rates on loans (which are typically longer term) and deposits (typically shorter term), with implications on banks' NIMs. Real GDP growth reflects the business cycle which affects banking sector activity and NIMs. The short-term real interest rates control for the banks' marginal cost of funds while the EMBI spreads control for sovereign creditworthiness which also affects the banks' funding costs.

The variable Access is the financial market access index from the Financial Development Index database.

\section{Baseline Results}

Regression results for the baseline specification are presented in Table $2 .{ }^{8} \mathrm{We}$ find that consistent with previous literature, in general, more competitive environment is associated with lower NIMs, but the entry of foreign banks and M\&A activities may be associated with higher NIMs.

- $\quad$ Lower NIMs are associated with less concentrated markets. This finding is consistent with that of Martinez Peria and Mody (2004). The effect is statistically significant when using the HHI or the top three banks' share as a measure of concentration. The results hold whether we use total asset concentration or total loan concentration. One standard deviation increase in the top three banks' share is associated with over 110 basis points higher NIM, a large effect. Interpretation of this result is not straightforward, however. First, high concentration does not imply low competition, as pointed out in section I. Moreover, concentration could be a response to profitability environment, raising concern on reverse causality.

- $\quad$ Foreign banks have lower NIMs on average, but the NIMs increase with its market share. Perhaps benefitting from economies of scale due to their global networks, foreign owned banks are able to charge lower NIMs. All else equal, foreign banks' NIMs are around 100 basis points lower than those of domestic banks. However, results show that NIMs do go up with the market share of the foreign bank. This suggests increased ability to exert market power as the foreign bank becomes more dominant. Alternatively, the higher NIM may reflect the increased production costs from having a more extensive local presence.

- $\quad M \& A$ activities involving foreign banks are associated with higher NIMs. Since M\&A increases banking sector concentration but possibly also the efficiency of the new entity, its ex ante impact on the NIM is unclear. In fact, like Martinez Peria and Mody (2004),

\footnotetext{
${ }^{8}$ As a robustness check, we also tried a specification with bank fixed effect instead of country fixed effect. Most results are robust to this varia tion, but foreign banks do not have lower NIMs on average, and there is no sta tistically significant rela tionship between market concentration and NIMs.
} 
we find that M\&As by foreign banks are associated with higher NIMs, but total M\&As including both local and foreign banks are not. This may suggest that less efficient domestic banks with higher NIMs are the usual targets of foreign takeovers, consistent with model predictions by Nocke and Yeaple (2007) and Neary (2007) that less efficient companies ("lemons") are the likely targets of cross-border M\&A. This said, some caution is needed to interpret our findings as if we take a 1 or 2 -year lag of foreign M\&A dummy, this association disappears.

We also confirm that bank specific characteristics, including banks' costs and income structure, matter for NIMs.

- $\quad$ Bank-specific characteristics can explain differences in NIMs. Higher levels of liquidity are associated with lower NIMs - each percentage point increase in liquid to total assets is associated with a 2 basis points decrease in the NIM-likely as a result of the lower interest income generated by liquid assets (Yuksel and Zengin, 2017). ${ }^{9}$ Similarly, banks with higher shares of non-performing loans (NPLs) also see lower NIMs as the inability to collect interest on loans diminish the banks' interest income. Banks with higher equity ratios on the other hand see higher NIMs, perhaps as a result of lower funding costs and dependence on external funding which lowers the need to offer high deposit interest rates. Quantitative effects of these bank-specific characteristics are similar to each other: one standard deviation change of each of them are associated with 40-70 basis points changes in NIMs.

- $\quad H i g h e r$ administrative costs are associated with higher NIMs. This result confirms the findings by others such as Cardim de Carvalho et. al (2012) and Williams (2007) that high operational costs may explain the high NIMs in some countries. Quantitative effect of this variable is very large. A one-standard deviation increase in administrative costs is associated with 440 basis points increase in NIM.

- $\quad$ Banks with higher fee incomes have lower NIMs. This suggests that more diversified income sources may allow banks to charge lower margins for intermediation as they can recoup the foregone income from other services. It is also possible that the causality runs in the opposite direction: banks with lower NIMs may make more efforts to diversify income sources, leading to higher fee incomes.

We also confirm that Macroeconomic conditions influence NIMs. We find that higher NIMs are associated with stronger real GDP growth and higher real interest rate. ${ }^{10}$ The positive impact of

\footnotetext{
${ }^{9}$ Martinez Peria and Mody (2004) and Gelos (2006), in contrast, find a positive rela tionship between liquidity and NIMs, which they interpret a s banks having to charge higher spreads for theopportunity cost of holding liquid a ssets (by prudence or regulation).

${ }^{10}$ MartinezPeria and Mody (2004) also find positive, a lbeit insignificant, effects of GDP growth and the real interest rate on NIMs. Gelos (2006) finds a negative rela tionship between GDP growth and NIMs.
} 
GDP growth, holding constant credit levels in the economy, real interest rates, and inflation, indicates a business cycle impact where increased economic activity may lead to banks adjusting their margins. The positive impact of the real interest rate suggests that higher rates raise the interest charged on loans by more than that offered on deposits. We also find that NIMs decrease with total credit in the economy and EMBI spreads. The former may reflect a supply effect—all else equal, banks competing to extend credit would lead to lower margins. The latter finding for EMBI spreads may be associated with lower funding costs for banks domiciled in more creditworthy countries which allow them to have higher NIMs.

Because our data sample covers the periods before and after the Global Financial Crisis (GFC), we are also able to observe the structural changes in the banking sector that have taken place since 2008. Dividing the sample into pre-GFC (1988-2007) and post-GFC (2009-2018), we find the margin differentials between domestic and foreign banks have more than halved since 2008 . Possible reasons for this narrowing include improved efficiency among domestic banks and postGFC retrenchment of western foreign banks from the region and their replacement by regional foreign banks which are more similar to domestic banks. We also find that margin differentials between private and public banks also diminished which likely reflects a smaller role of public banks in directed credit subsidies in recent years. The low global interest rates in the post-GFC years likely also played a role in forcing a tightening of margins across all banks. These results are reported in Table 3.

As a robustness check, we replicate the baseline regressions with banks' markups rather NIMs as the dependent variable. Markups are measured by the Lerner Index as estimated by Igan and others (2020). Results, presented in Table 4, confirm the broad findings of the NIM regressions, with differences likely reflecting the fact that NIMs and markups do not consistently point in the same direction, as discussed in Section I. Higher markups are associated with higher market concentration, albeit with a lower degree of statistical significance than in the NIM regressions. Results show that foreign banks on average have lower markups. And while public banks do not have NIMs that are statistically different from those of non-public banks, the Lerner regressions show that public banks on average have higher markups. As with findings for NIMs, macroeconomic conditions also impact banks' markups. Notably, higher real GDP growth and higher real interest rates are associated with lower markups, which suggest that banks' NIM adjustments during periods with high growth or high real rates, as discussed above, may be in response to changing profit margins. Similar to NIMs, markups also decrease with total credit in the economy and EMBI spreads.

A key takeaway from the baseline regression results is that whether fintech would enhance banking sector competition would depend on how and in what forms fintech enters the market. Fintech will bring new technology to reduce the overall costs structure in the banking system, but unless Fintech entries enhance competition between banks and fintech companies, costs of financial services would not fall (as the regression results on foreign banks and M\&A activities suggest). That said, anecdotal evidence suggests that banks have increased IT investment, as well 
as direct investment in fintech startups in recent years, implying that banks see fintech firms as a potential threat. If so, fintech could contribute to enhancing competition.

\section{Regressions Incorporating Fintech}

We next turn to the question of whether fintech activities in the region have already had an impact on banks' margins. With the baseline results identifying variables that matter for the NIM, we conduct a difference- in- differences regression exercise to test for effects of fintech while controlling for the aforementioned variables. It is important to note that this is an exploratory exercise - to understand whether the early impact of fintech already shows up empirically — and therefore must be heavily caveated. Quantitative information on fintech in LAC remains sparse. And while fintech has been growing rapidly in some countries in the region, its overall volume remains very small. Fintech lending in the countries for which we have data makes up only about 0.02 to 0.05 percent of total loans. Countries in our sample with fintech lending activity, as identified by the Cambridge Center for Alternative Finance, are shown in Figure 7. ${ }^{11}$

Figure 7. Fintech Lending (\$ million)

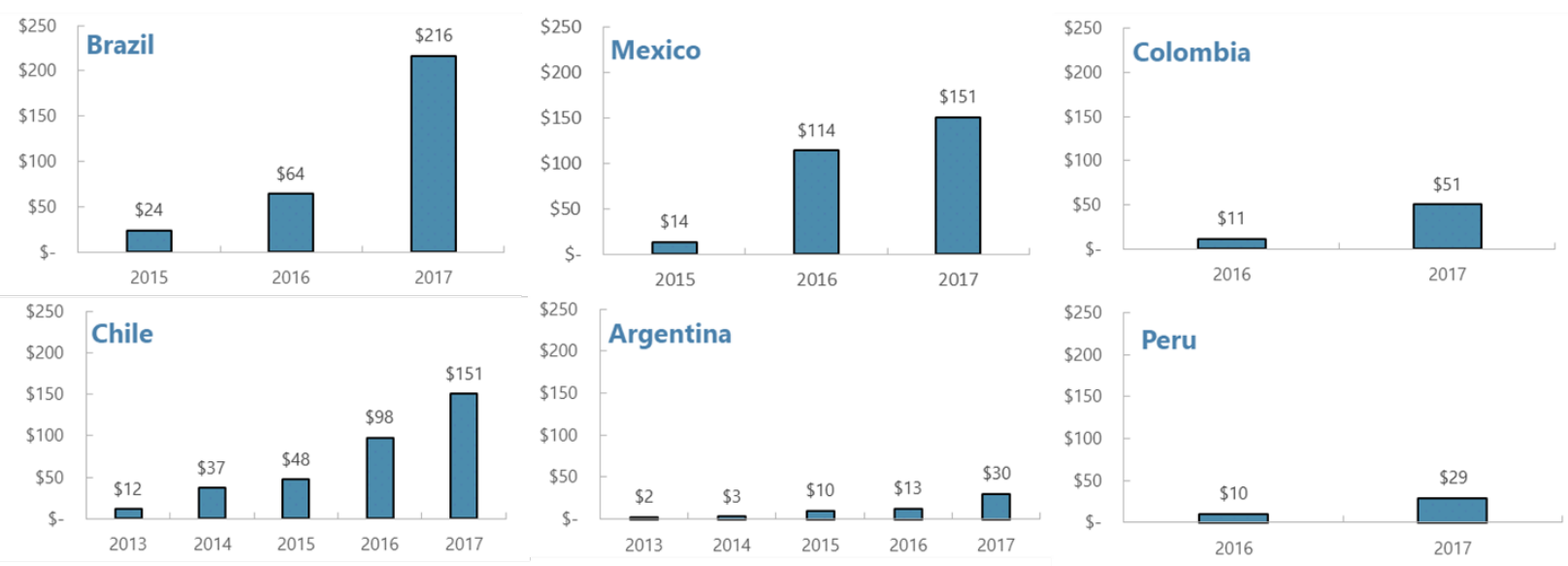

Source: Cambridge Center for Alternative Finance (CCAF).

We specify the following regression model:

$$
N I M_{i c t}=\beta_{0}+\beta_{1} D_{t>2012}+\beta_{2} D_{\text {Fintech }}+\beta_{3} D_{t>2012} D_{\text {Fintech }}+\beta_{4} X_{i c t}+\varepsilon_{i c t}
$$

\footnotetext{
${ }^{11}$ While fintech is present in a broader set of countries in LAC, we focus on fintech lending due to its potential impact on banks' NIM. Quantitative analy sis of fintechs' impact on banks' non-lending a ctivities is beyond the scope of this paper, but is a $n$ interesting future research topic.
} 
where $D_{t>2012}$ equals 1 for time periods after 2012 when fintech activity started to take place in the region; $D_{\text {Fintech }}$ equals 1 for countries shown in Figure 7 . The definition of these two dummy variables is based on the interpretation that fintech lending existed only in years and countries in which the CCAF data existed. $X_{i c t}$ are the control variables from the baseline regressions. ${ }^{12} \mathrm{We}$ also test an alternate specification where $D_{\text {Fintech }}$ is replaced by the volume of fintech credit to total credit in the economy - a measure of fintech "intensity." The diff-in-diff coefficient of interest is $\beta_{3}$, the marginal impact of having fintech within country on NIM.

\section{Fintech regression results}

The difference in differences results are reported in Table $5 .{ }^{13}$ Findings for the variables from the baseline regressions are consistent with the results described in the previous section. Again, market concentration is associated with higher NIMs. For the fintech variables, we find that the diff-in-diff coefficient has the expected negative sign, suggesting that banks in fintech countries have seen greater reductions in NIMs than those non-fintech countries in the periods after fintech lending emerged. Unobserved time-invariant differences between fintech and non-fintech countries are controlled for by $\beta_{2}$, which indicates a positive and significant relationship between countries with fintech lending activities and NIMs, consistent with the finding that fintech has tended to develop in countries with high intermediation prices where alternative financial solutions are of greatest value (Mansilla-Fernandez, 2017).

As noted earlier, quantitative findings at this early stage of fintech development should be interpreted with caution. As progress in this area continues, the evolution of fintech within the banking sector will shape the data that will become available for further empirical studies. The methodology laid out in this section could serve as a useful point of departure for future analyses of the effect of fintech on the banking sector. Until further quantitative analyses can be done, case studies can provide insights on how fintech has developed in some countries and the impact it has had thus far. We turn to two case studies in the next section.

\section{Fintechin LAC: CASE Studies}

As noted at the beginning, the fintech evolution and its impact on banking sector competition will depend on how incumbent banks and regulators respond to these new forces. In this section, we take a closer look at fintech in Brazil and Mexico- the two most developed fintech markets

\footnotetext{
${ }^{12}$ Country, year fixed-effects are not included as they would overlap with $D_{t>2012}$ and $D_{\text {Fintech }}$.

${ }^{13}$ Given the uncertainty on the timing that fintech a ctivities became substantial enough to affect competitive environment, we ran another version replacing $D_{t>2012}$ by $D_{t>2016}$. Results did not change materially a s all signs and most of the statistical significance did not change, but $\beta_{3}$ loses statistical significance.
} 
in the region. Despite substantive differences in their banking systems, Brazil and Mexico have the largest market sizes in Latin America and financial authorities who have embraced financial innovations as potential opportunities to improve the banking sector, providing ideal conditions for fintech growth.

While there are many differences between the two case studies, some common threads do emerge:

- Both fintech and bigtech are progressing more rapidly for the payments segment than for lending.

- Many fintech startups are focusing on niche markets and unbanked population, which helps enhance financial inclusion.

- Incumbent banks are responding by investing in innovation, hence improving their efficiency and customer service.

- Some incumbent banks are partnering with fintech startups. On one hand, this could improve financial sector efficiency and productivity. On the other hand, the impact on competition is not clear as banks may increase their markups rather than reducing fees or interest rates as a result of these efficiency gains.

- There are encouraging signs in both Mexico and Brazil that, for the payments segment, fees are declining.

\section{A. Fintech in Brazil}

Brazil has a vast banking sector, with assets totaling around 105 percent of GDP. The sector is dominated by large banks - the five largest account for over 80 percent of total assets - with NIMs that are among the highest in the world. While the share of adult population with financial accounts is relatively high at 86.5 percent (Central Bank of Brazil, 2018), Brazil's large population implies that tens of millions of potential financial accounts still remain untapped. It is unsurprising therefore that Brazil is LAC's largest and fastest growing fintech hub with more than 650 fintech companies operating in the country at end-2019 (Figure 8).

Figure 8. Fintech Development in Brazil

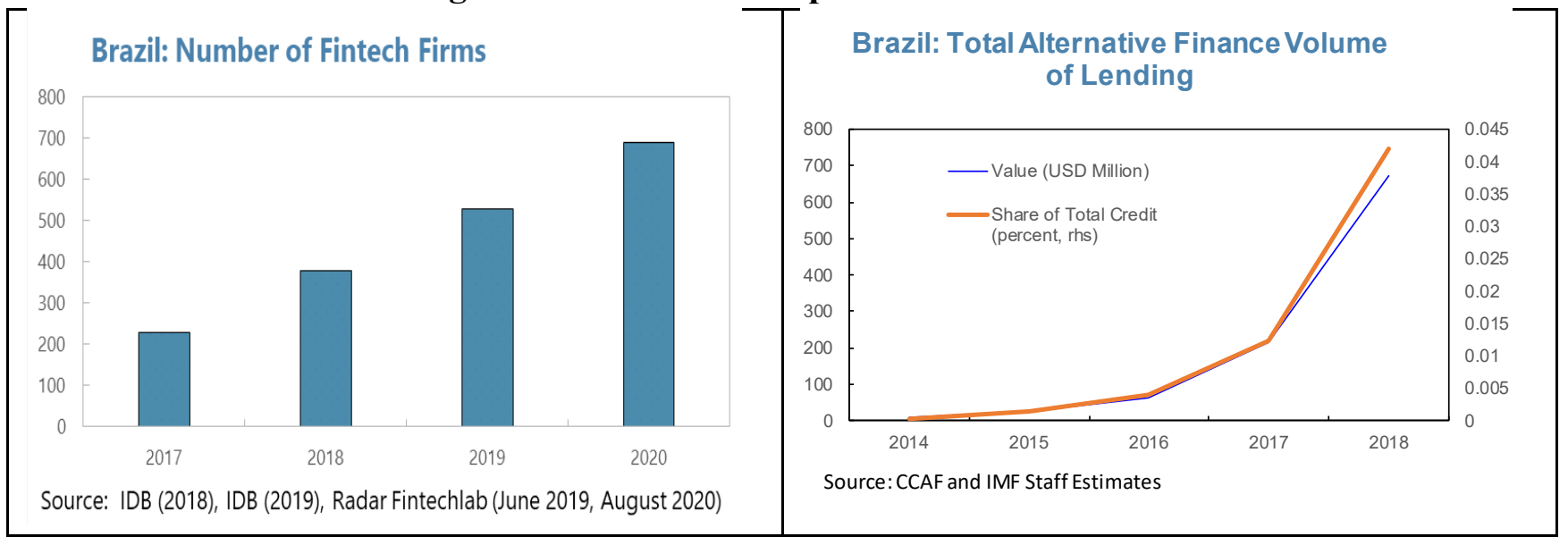


Fintech companies typically operate in narrow lines of business in which they have comparative advantages, often targeting populations underserved by existing banks such as those with limited formal credit history. Several fintech startups in Brazil have grown rapidly, with some such as Nubank (Brazil's largest fintech company), Creditas (largest fintech for secured loans), and Stone (fintech for merchant payments processing) having attracted substantial external financing. ${ }^{14}$ Some fintech firms enter the market in partnership with banks or other licensed entities to avoid the heavy regulatory burden of obtaining licenses, although, as discussed further below, regulations have recently been passed to facilitate fintech licensing. Other fintech firms have opted to be licensed as non-bank financial institutions. For example, Nubank which offers digital bank accounts and personal loans has two licenses: Credit, Finance, and Investment Companyand Payment Institution.

Growth in fintech has also benefited from the entry of "bigtechs" into this space. For example, the largest regional e-commerce company, the Argentine MercadoLibre, also owns the payment processing fintech company MercadoPago and the lending fintech company MercadoCredito. Bigtechs with global presence (such as American and Chinese bigtechs) initially focused on their main business lines, such as e-commerce and its associated payment systems, but have since begun to invest in other types of fintech and become more directly involved in the domestic financial markets. The latest example is the June 2020 announcement by Facebook Inc's messaging platform WhatsApp on the launch of its digital payments service, WhatsApp Pay, in Brazil. With over 100 million users, the platform has the potential to improve financial inclusion by reaching a wide segment of the unbanked population and increase payments efficiency. While the new service could erode the fee incomes banks currently earn on payment and transfer services, assessing the impact on banking sector competition is not straightforward. For example, WhatsApp Pay originally planned to partner Cielo, the payments processor owned by the biggest banks in Brazil (Banco do Brasil and Banco Bradesco). In this context, the increased profitability and asset values could further increase banking sector concentration. ${ }^{15}$

\footnotetext{
${ }^{14}$ Nubank has received investments from Goldman Sachs a nd Tencent, and Creditas from Sa ntanderInnoventures and Softbank, a mong others. Stone had an IPO in 2018.

${ }^{15}$ Due to concerns a bout its size and the impact on competition, the regulatory a pproval process of WhatsApp Pay was initially delayed to a llow the authorities to have sufficient time to conducta nalyses. Subsequently, in April 2021, WhatsApp Pay was authorized a s a payment initiator in Visa and MC's transfer schemes. WhatsApp in still forbidden to operate in purchase schemes. Therefore, WhatsApp is only allowed to facilitate peer-to-peer (P2P) payments, butnot for purchases from merchants.
} 


\section{The regulatory response}

The Brazilian authorities have welcomed fintech as a positive development in the financial sector. They have largely accommodated the presence of fintech in the financial system with specific fintech-related legislations within the existing regulatory and legal frameworks rather than producing a separate framework for fintech (e.g., as was done in Mexico). The Brazilian regulatory approach follows the principles of segmentation and proportionality, i.e., with rules tailored to reflect the size, activities, and risk profile of each entity. The financial regulatory authorities which include the National Monetary Council (CMN), the Central Bank of Brazil (BCB), the Securities and Exchange Commission of Brazil (CVM), and the Superintendence of Private Insurance (SUSEP) issue specific regulations within their mandates, following the principle of proportionality. In this framework, most fintech firms would be subject to less complex authorization processes than big financial institutions.

The move to include and facilitate fintech activities in the financial sector is in line with the authorities' ongoing efforts to deregulate and increase competition in the banking sector. In 2016, the Central Bank of Brazil (BCB) introduced Agenda BC+ aimed at tackling structural issues in the financial system including aligning regulations to international standards, promoting financial education and inclusion, and promoting a more competitive and efficient system. More recently, the BCB launched Agenda BC\# ("BC hashtag") which added new dimensions and strengthened Agenda $\mathrm{BC}+$. The latest agenda aims to promote inclusion, competitiveness, transparency, financial education, and sustainability.

Important regulations related to fintech in recent years include those in the following areas:

- $\quad$ Payments services. BCB Circular 3682 (November 2013), BCB Circular 3885 (March 2018), and BCB Resolution 80 (March 2021) which revoked Circular 3885. There are four types of services allowed to be carried out by payment institutions: (i) electronic money issuer; (ii) post-paid payment instrument issuer; (iii) acquirer; and (iv) payment transaction initiator (PISP). For post-paid payment instrument issuer and acquirer, services can be exempt from licensing based on the volume or number of users..

- $\quad$ Securities market. Regulation 588 (July 2017, by CVM) allows crowdfunding platforms more scope to grow by creating an exception to the general rule that public offerings of securities in the Brazilian market must be registered with the CVM. Equity issuances by small enterprises via electronic crowdfunding platforms are exempted from this registration, provided certain conditions are met.

- $\quad$ Credit market. CMN Resolution 4656 (April 2018) provides for the creation of two new types of financial institutions that originate credit through digital platforms: (i) direct credit companies (Sociedade de Crédito Direto or SCD) that make loans through electronic platforms with own capital; and (ii) P2P loan companies (Sociedade Entre Pessoas or SEP) that facilitate loans between creditors and debtors made via electronic 
platforms. ${ }^{16}$ Under CMN Resolution 4656, fintechs can offer services, for which they previously needed to partner with traditional banks, under a simplified licensing process. Since 2019, 24 SCDs and 6 SEPs have been licensed.

- $\quad$ Open banking. In May 2020, the BCB announced regulations on open banking, following previous guidelines issued under Communique 33455 in April 2019. Open banking would cover financial institutions and other institutions licensed by the Central Bank and include the sharing of information on products and services offered by participating institutions and, per customers' consent, customers' personal and transactional data. Implementation started in February 2021 and will become fully operational by end- 2021 .

- Regulatory sandbox. BCB, CVM, SUSEP, and the Ministry of Economy published a joint statement in June 2019 on their intention to create regulatory sandboxes to promote financial innovation. The three regulators (BCN, CVM and Susep) have since approved the rules for their sandboxes. Both licensed and unlicensed institutions will be able to participate. Susep already selected the projects to be tested in the first cycle and some of them are already operating. $\mathrm{BCB}$ and $\mathrm{CVM}$ are going through the projects' selection and there is an expectation that the projects will begin their operation in the second half of 2021.The duration of one cycle (or "cohort") may differ depending on the sandbox of different authorities (every 2 or 3 years). In the first cycle, Susep authorized 11 projects, $\mathrm{CVM}$ will authorize 7 projects and $\mathrm{BCB}$ between 10 and 15 . While the aim is to customize the sandbox to each participant, Brazil's civil law tradition implies detailed statutes, which may limit the flexibility of the sandbox.

Along with the regulations, open banking, and regulatory sandbox, the authorities are also directly encouraging innovation. In 2018, the BCB launched the Financial and Technology Innovation Laboratory (LIFT), a program that aims to promote technological innovation in financial activities in order to increase efficiency and reduce the cost of credit.

\section{Impact on competition and responses of incumbent banks}

Despite the rapid growth, fintech still accounts for a very small share of banking sector activities in Brazil. However, there is some evidence that the changing landscape has forced incumbent banks to reevaluate prices and services offered as well as operational efficiency.

\footnotetext{
${ }^{16}$ Creditas and Nexoos are examples of, respectively, a SCD offering balance-sheet lending and a SEP offering P2P lending that received a license under CMN4656.
} 


\section{Payments}

The most visible effect of fintech thus far has been in payments. One example is the merchant discount rate (MDR), a payment processing fee charged to businesses by merchant acquirers. ${ }^{17}$ Due to de facto exclusivity contracts to acquire merchants, the market was that of a duopoly until mid-2010 (Garber and Nakane, 2015). ${ }^{18}$ The competition authority (CADE)'s efforts to eliminate exclusivity deals led to the entrance of other acquirers including fintechs and bigtechs such as Stone and PagSeguro. With more than 20 competitors and the market share outside the two original incumbents approaching 30 percent, MDRs have fallen from nearly 3 to around 21/2 percent (Figure 9).

Figure 9. Developments in Payment Card Acquisition Market Lending

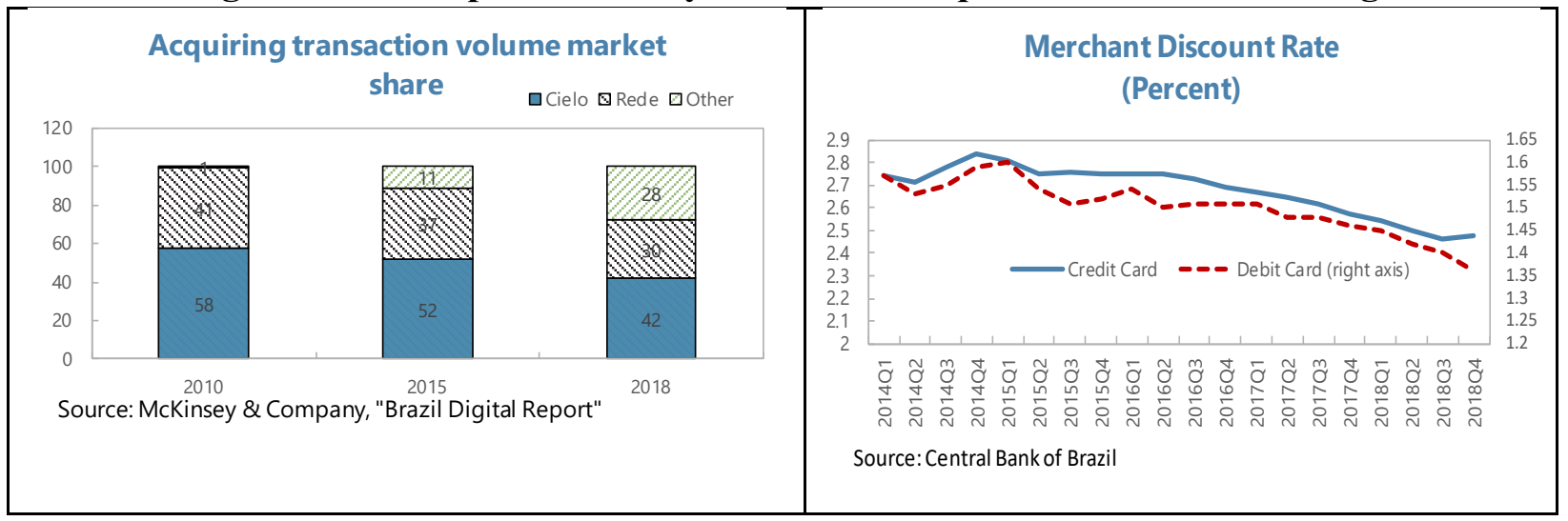

At the current juncture, fintech lending in Brazil does not appear to have substantively altered lending prices by traditional banks. Credit by fintech lenders (e.g., Banco Inter, Banco Original) is growing several folds faster than the largest banks (Figure 10), but their sizes remain quite small (Figure 11). ${ }^{19}$ Moreover, rather than directly competing with banks in lending, many fintech companies have concentrated on market segments thus far excluded by incumbent banks while some are directly collaborating with incumbent banks. As the explosive pace of fintech credit expansion continues, however, the question is not one of whether but how quickly banks' NIMs will be impacted.

\footnotetext{
${ }^{17}$ Credit card issuers a dd ca rdholders to the network and serve them, while card acquirers a dd and serve merchants. Issuers and a cquirers can be but a re not necessarily the same entities (Garber a nd Nakane, 2015)).

${ }^{18}$ Cielo had a nexclusivity contract to acquire merchants for Visa, while Rede had a practical, if not formal exclusivity to acquire merchants for MasterCard.

${ }^{19}$ Da ta for some relevant fintechs, such as the digital bank arm of existing large banks (e.g., Banco Next) and lending by e-commerce firms (e.g., MercadoCredito) were not available and thereforenot included in the figures.
} 
Figure 10. Growth Rates of Lending: Fintechs v. Largest Banks

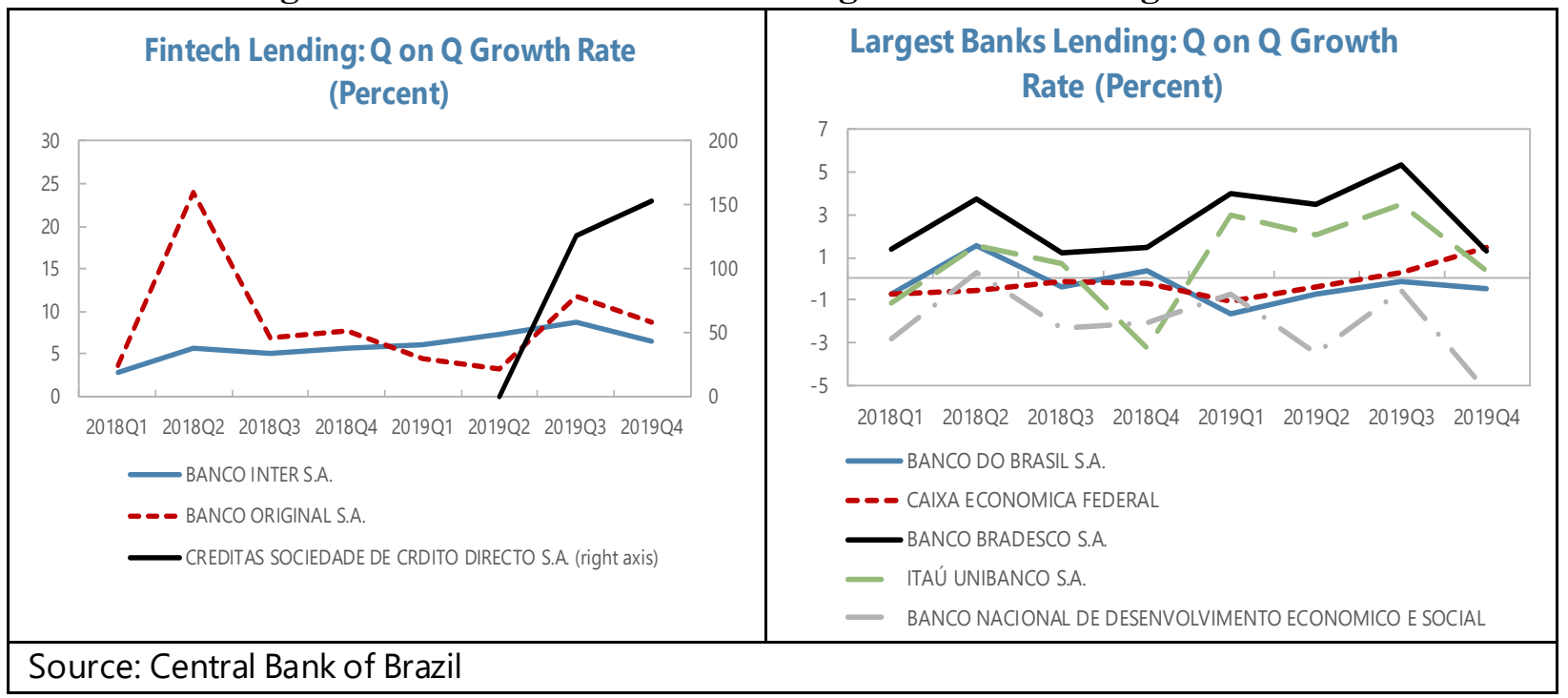

Figure 11. Shares of Lending: Fintechs vs. Largest Banks

\begin{tabular}{|l|l|l|}
\hline $\begin{array}{c}\text { Fintech lending: Share of Total Credit } \\
\text { (Percent) }\end{array}$ & \multicolumn{2}{c|}{$\begin{array}{c}\text { Largest Bank Lending: Share of Total } \\
\text { Credit (Percent) }\end{array}$} \\
\hline \\
\hline
\end{tabular}

While fintech's effects on banks may not yet be quantitatively apparent, the entry of fintech companies accelerated the digitization of banking services by incumbent banks to preserve market share and increasing operational efficiency to preserve margins (e.g., by reducing the number of branches as shown in Figure 12). Some incumbents have adopted fintech products, e.g., Banco Bradesco launched the fully digital bank Next, and Banco do Brasil and Bradesco partnered to launch a digital credit card. Some, such as Banco Original and Banco Inter, which started off as traditional banks, have converted to digital banks. Many are directly funding fintech startups by establishing innovation hubs such as Cubo Itaú, Bradesco's InovaBra, and Banco do Brasil's fintech lab in Silicon Valley. Such partnerships have appeared mutually 
beneficial as incumbents take part in fintech innovation while fintech startups benefit from the banks' resources, experience, and licenses to undertake financial activities.

\section{Figure 12. Trends in Incumbent Banks}

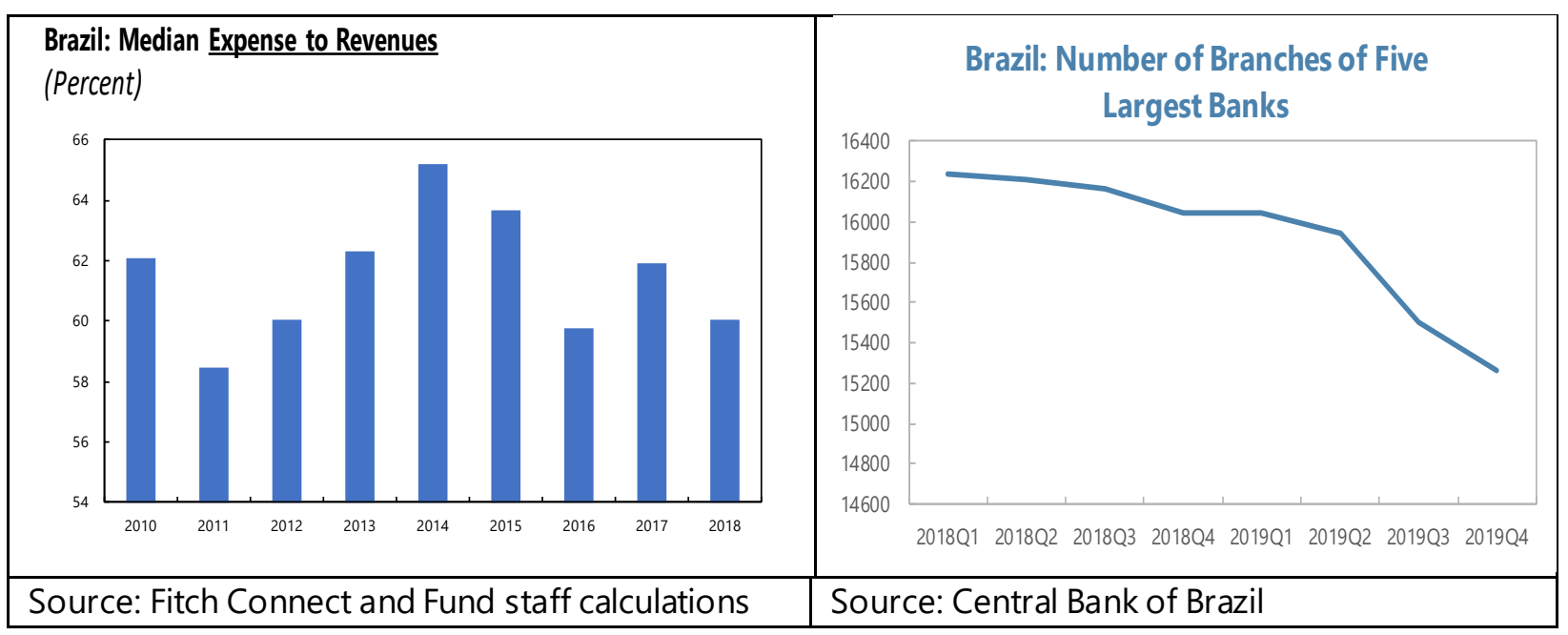

\section{B. Fintech in Mexico 20}

The fintech industry in Mexico is among the most developed in Latin America, both in terms of the number of firms and the size of credit. In 2018, Mexico passed the first comprehensive fintech law in Latin America, followed by the issuance of secondary regulations. Reaction to the secondary regulations has been mixed - while some have praised them for providing greater certainty and security, others are concerned about the high compilation costs. Only 2/3 of the fintech entities that require a license to operate under the secondary regulations applied by the deadline and its approval has been stalled since the onset of the Covid-19 pandemic. While striking the right balance among enabling financial innovation, providing consumer protection and maintaining financial stability continues to be a challenge, resumption of the approval process to the extent allowed by the pandemic would help maintain the dynamics of fintech development.

\section{Background}

In Mexico, the banking sector is dominated by foreign banks. Of the seven largest banks by assets, only two are domestically owned..$^{21}$ The five largest banks account for about 70 percent of total assets. Despite a relatively sophisticated banking system, the Mexican banking sector is

\footnotetext{
${ }^{20}$ Based on interviews with the Bank of Mexico, the Na tional Banking and Securities Commission (CNBV), and the Ministry of Fina nce(SHCP) during February-March 2020

${ }^{21}$ The la rgest banks in Mexico are BBVA, CitiBanamex, Santander, HSBC, Scotia (all foreign), Inbursa, and Banorte (domestic).
} 
small compared to others in the LAC region. Banking sector assets are around 40 percent of GDP and bank credit as a share of GDP is only about a quarter of the level observed in other emerging markets, including Brazil (Herman and Klemm, 2017). These figures are reflective of low financial inclusion in Mexico, where only 47 percent of the adult population have financial accounts and around 70 percent of individual borrowers rely on informal credit through pawnbrokers, savings groups, or other individuals. ${ }^{22}$ The credit market survey conducted by the Bank of Mexico (Banxico) for 2020Q2 shows that only one-third of companies identified commercial or foreign banks as their main source of financing. ${ }^{23}$ Those without access to formal credit are forced to borrow from the more expensive informal sector. The low access is particularly notable among younger firms and start-ups due to their limited credit history (World Bank, 2016).

According to Finnovista, ${ }^{24}$ since 2016 the number of fintech startups has been growing at an average annual rate of 23 percent. By March 2020, the number has reached 441 . The mortality rate of fintech startups also decreased from 11.3 percent in 2018 to 4.5 percent in 2020. Fintech firms provide a wide array of financial services, but most engage in payments and transfers ( 88 firms) and consumer and business lending (83 firms) (Finnovista, 2020). The amount of fintech credit has grown dramatically over the recent years; however, it still accounts for a small share of total formal credit (0.06 percent) as of 2018 (Figure 13).

\footnotetext{
${ }^{22}$ Encuestra Nacional de Inclusión Fina nciera (ENIF) (2018) conducted by the Na tional Banking and Securities Commission(CNBV) and the Na tional Institute of Statistics and Geography (INEGI).

${ }^{23}$ Source:

https://www.banxico.org.mx/SieInternet/consultarDirectorioInternetAction.do?accion=consultarCuadro \&idCuadro= $\underline{\text { CF471\&sector }=19 \& \text { locale }=\text { en }}$

${ }^{24}$ Finnovista covers a broader spectrum of fintech services (including finance and wealth management, insurance, fina ncial education, and trading pla tforms) than those regulated by theFintech Law, a s discussed in the following section.
} 
Figure 13. Fintech Development in Mexico

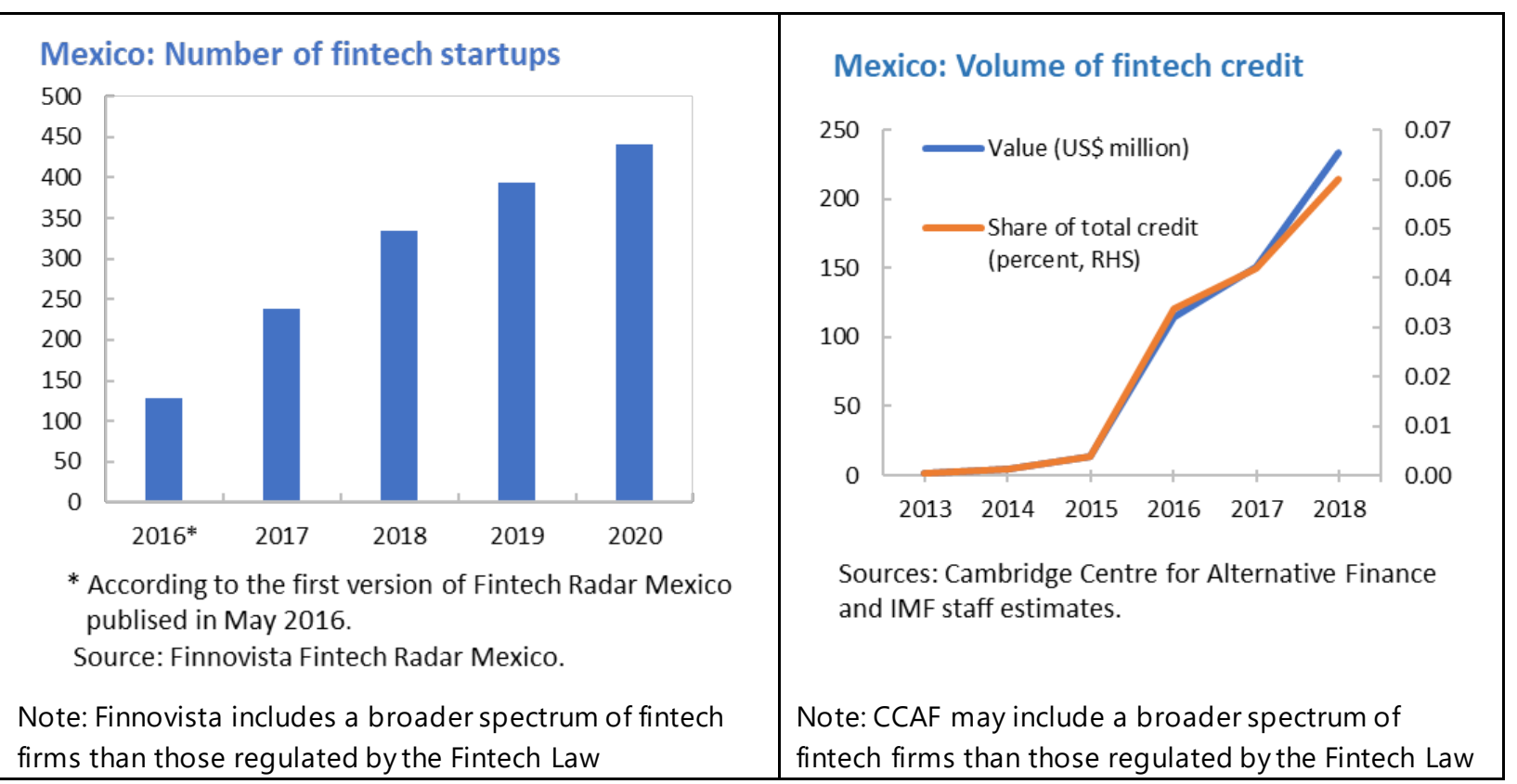

Many of the expanding fintech startups have tended to focus on SME lending or microcredits, filling the niche of the credit market underserved by traditional banks. Credijusto and Konfio, for example, are fintechs specialized in SME loans that have received significant external funding which enabled them to expand further. Kueski, one of the largest online lenders in Mexico specialized in short-term microloans to individuals, applies Bigdata analytics and machine learning to process loan applications, with a decision usually made within 24 hours. ${ }^{25}$

Bigtechs are also increasing their presence in Mexico's booming fintech industry. Konfio, for example, has partnered with Facebook and PayPal to take advantage of their advanced data analytics for faster and more reliable loan processing. Amazon has entered the payments segment with its launch of Amazon Cash in Mexico in 2017, which allows users to deposit cash into their accounts at convenience stores and other merchants which can then be spent with their mobile phones. Amazon also partnered with Banorte and launched in 2018 Amazon Rechargeable, a virtual debit card funded by cash deposits at convenience stores that does not require visits to a bank branch.

\footnotetext{
${ }^{25}$ Creditjusto, Konfio, and Kueskiengage in a ctivities that are outside the coverage of the Fintech Law. Source of company information is the Crunchbase database.
} 


\section{The regulatory response}

\section{A fintech regulatory framework}

Recognizing the growing role of fintech in the financial sector, the Mexican authorities developed the Fintech Law ("the Law") which was enacted in March 2018 and is the first comprehensive fintech legislative framework in Latin America. The Law seeks to provide legal certainty to fintech investors, consumers, and companies. It is based on the following guiding six principles: (i) promote financial inclusion and innovation, (ii) foster competition, (iii) protect consumers, (iv) strengthen AML/CFT, (v) maintain financial stability, and (vi) observe technological neutrality. The Law recognizes and regulates two types of fintech institutionscrowdfunding (which includes peer-to-peer lending) and e-money platforms, (both referred to as "Financial Technology Institutions (FTI)) - and three other areas related to fintech:

- Virtual assets (also known as crypto assets), as defined within the Law and can only be used by FTIs and banks for specific operations, with their use subject to authorization by Banxico;

- $\quad$ Application programming interfaces (APIs) must be developed by all financial entities including FTIs, traditional banks, credit bureaus, and clearing houses for the purposes of connecting and sharing information with each another;

- Regulatory sandboxes permit commercial firms and traditional financial institutions to temporarily test and operate innovative models of financial services.

The Law designates Banxico, the National Banking and Securities Commission (CNBV), and the Ministry of Finance (SHCP) as the main regulators for the fintech industry. ${ }^{26}$ The regulation of e-money platforms, virtual assets, and the use of foreign currencies falls primarily on Banxico. $\mathrm{CNBV}$, under the Law, is responsible for prudential regulations for FTIs such as capital requirements, corporate governance, and risk management. $\mathrm{SHCP}$ is responsible for AML/CFT regulations.

The introduction of APIs paves the way for open banking which could facilitate competition in the financial system. The aim is to allow mutual sharing of: (i) open financial data, including information about financial products and services offered to the public; (ii) aggregated data, which are statistics that do not reveal the identities of clients; and (iii) transactional data, only with the client's prior consent. Financial entities and third parties specialized in information technology can request access to other entities' interface subject to a discretionary fee and prior approval from the corresponding regulators. The ultimate objective of open banking is to promote transparency and foster competition.

\footnotetext{
${ }^{26}$ Along with the National Commission for the Protection and Defense of the Financial Services Users (CONDUSEF), the Na tional Commission for the Pension System (CONSAR), a nd the Na tional Bonding and Insurance Commission(CNSF).
} 
To promote innovation, a regulatory sandbox is created by the Law to provide legal flexibility for new financial models. The sandbox allows (i) non-regulated entities to operate temporarily without the need to apply for a full license as a financial entity and (ii) regulated entities to test a new business model without full compliance with the regulatory requirements. CNBV has been actively communicating with the public to promote the regulatory sandbox, including organizing the financial innovation contest "Sandbox Challenge" with the support of the UK government, where winners receive legal and business advice to support their sandbox applications. Although there has been no successful application for the sandbox as of March 2020 prior to the Covid-19 pandemic, engagement between CNBV and interested entrepreneurs on their eligibility are ongoing.

In addition to the regulatory sandboxes and the move towards open banking, the Mexican authorities are also directly facilitating fintech development with the launch of the digital payment system Cobro Digital Systems (CoDi) that allows customers to make payments online and in person through smartphones free of charge using QR codes. Built by Banxico, CoDi had five million users as of September 2020 with all traditional banks are participating in the system. Both Amazon and MercadoLibre have also approached the central bank about adopting the QRcode-based payment system.

\section{Secondary regulations}

Since the Law was enacted, secondary regulations that govern the implementation of the Law have been published in September 2018. Under the secondary regulations, companies that engage in the fintech activities governed by the Law were required to apply to the CNBV by September 2019 for a formal FTI license to operate. Those who failed to comply would have to cease operation, according to the transitory provision of the Law. Banks that wished to carry out or continue with fintech operations not covered by the banking law were also required to establish FTIs and file applications. The secondary regulations also set forth additional requirements for licensed FTIs, including:

- $\quad$ Minimum capital stock of 500,000 UDIs (approx. US\$146,000) or 700,000 UDIs (approx. US\$204,000), depending on the type of fintech activities;

- Maximum limits on cash transfers per client and per day for electronic payment and crowdfunding platforms;

- Maximum limits on lending activities for crowdfunding and P2P platforms;

- $\quad$ Obligations for crowdfunding platforms to make investors diversify their resources across different projects; 
- $\quad$ Reporting requirements for anyone intending to acquire 10 percent or more of shareholding in a FTI.

In developing the secondary regulations, the Mexican authorities have considered the protection of consumers and investors, the promotion of financial innovation, and the mitigation of risks to the financial sector. Striking the right balance among these factors, however, is challenging. While some praised the Law for providing greater certainty and security to users, in a survey by Finnovista, 52 percent of fintech startups in Mexico said that the Fintech Law presents high barriers to entry to the market (Finnovista, 2019). A study conducted by Endeavor Mexico suggests that 63 percent of the existing fintech startups would not be able to absorb the estimated cost of complying with the secondary regulations. (Endeavor Mexico, 2019).

Potentially reflecting the additional regulatory burden, only $85^{27}$ out of the 124 fintech entities that require a license to operate as a FTI under the new legal framework have filed applications with the CNBV by the September 2019 deadline. About two-thirds of the applicants were emoney platforms, while the remaining one-third were crowdfunding or P2P lending platforms. Of these applicants, about 20 were foreign-owned entities. The applications were reviewed by a committee represented by Banxico, SHCP, and CNBV. In January 2020, the first license was issued to NVIO Pagos Mexico, the company that owns Bitso, an online trading platform for cybercurrencies with more than one million users across Latin America as of July $2020 .{ }^{28}$ The authorization process, however, has been interrupted since the onset of the Covid-19 pandemic.

\section{Impact on competition and responses of incumbent banks}

The impact of fintech on banking sector competition in Mexico has been most apparent in the digital payments market. With state-of-the-art technologies, fintechs are able to offer reliable and almost immediate payments and transfers with low fees. To ensure traditional banks' competitiveness, the Mexican Banking Association announced in March 2019, in response to a proposal by a member of Congress, the elimination of banks' commission fees charged on digital accounts and money transfers.

As with Brazil, the young and fast-growing fintech industry may have yet to quantitatively impact traditional banks' NIMs but the pressure on the banking sector in Mexico to innovate has been undeniable. Traditional banks are devoting more resources than ever to innovation. In addition to developing their online banking platforms, Santander Mexico, for example, established in 2017 a digital factory ("fábrica digital") called "Spotlight," dedicated to the development of innovative fintech products to better serve the bank's clients.

\footnotetext{
${ }^{27}$ The number of applicants would be 96 if the entities that engage in fintech activities not regulated by the Fintech Law are also counted.

${ }^{28}$ https://cointelegraph.com/news/bitso-hits-1m-users-as-crypto-adoption-spikes-in-latin-america
} 
Collaboration between traditional banks and fintech startups has also been increasing. In June 2020, Banorte announced that it is working with the food delivery startup Rappi on a joint venture aimed to provide innovative financial products that are integrated into users' daily life. ${ }^{29}$ Santander organizes a recurring competition called Radar Santander for fintech startups to present their business ideas. The winners are invited to collaborate with the Santander team at Spotlight to turn their ideas into products. BBVA organizes a similar program called Fast Track. Through this kind of competitions, the chosen startups could benefit substantially from the collaboration due to the large resources and client base that traditional banks have. Collaboration also occurs in the form of funding. Klar, a fintech startup that offers alternative financial service solutions, received US\$57.5 million of debt and equity funding from Santander in 2019, which was the largest seed funding round in Mexico. ${ }^{30}$

Traditional banks have also reacted to preserve their share in the booming digital payments market through M\&A. BBVA Mexico, for instance, acquired OpenPay, a fintech startup specialized in payments, in 2016. In February 2020, Santander announced their plan to acquire Elavon México, a merchant payment solutions company.

Finnovista foresees that fintech startups could take up to 30 percent of Mexico's banking market over the next decade. To allow healthy development of the industry, regulators need to strike a careful balance between promoting competition and protecting investors and customers in the design of regulations. Efforts to promote the regulatory sandbox and the approval of operating licenses under the secondary regulations should be resumed to the extent that is allowed by the pandemic to maintain the dynamics of fintech development.

\section{CONCLUDING REMARKS}

For countries in LAC, the rapid growth in fintech gives rise to opportunities for improved banking sector competition and financial inclusion. While the fintech industry is still new to the region, this paper presents early evidence of the impact it has already started to have on incumbent banks' behaviors and that it is associated with lower NIMs. Whether fintech will reduce banking sector concentration remains unclear. What is clear from the defensive responses by banks thus far, including fintech adoption, lowering of fees, and expansions into new markets, is that fintech can indeed bring about greater banking sector competition, and that we may just be seeing the tip of the iceberg. Open banking has the potential to be a gamechanger for fintech firms. Equal access to data within the financial system, including previously proprietary banks' customer data, could greatly level the playing field for fintech firms.

\footnotetext{
${ }^{29}$ Source: https://iupana.com/2020/06/29/rappi-banorte-jv-targets-innovative-financialservices/?lang=en\#widget/?lang=en

${ }^{30} \mathrm{https}$ ://news.crunchbase.com/news/klar-raises-57-5m-in-debt-and-equity-to-become-the-chime-of-mexico/
} 
The rise of fintech has also brought new challenges including data privacy concerns, cybersecurity, AML/CFT controls, and fraud. Financial systems regulators have the tough task of balancing the goal of greater innovation and competition with considerations on risks and financial stability, all while keeping pace with changes in the fintech space. This balancing act, however, holds the key to fintech's integration into the financial system. Looking forward, as fintech grows and transactions increasingly move across borders, international collaboration among financial regulators is likely to play a key role in shaping the future of fintech. Such collaboration would allow for collective surveillance, sharing of knowledge and best regulatory practices, and the prevention of regulatory arbitrage. 


\section{References}

Agur, I., S.m., Peria, and C. Rochon, 2020, "Digital Financial Services and the Pandemic: Opportunities and Risks for Emerging and Developing Economies," IMF Special Series on COVID-19, July.

ABFintechs/PwC, 2018, "Brazil Fintech Deep Dive 2018."

Beck, T., Demirguc-Kunt, A., and Levine, R., 2003 "Bank Concentration and Crises," NBER Working Papers 9921, National Bureau of Economic Research.

Berkmen, P., Beaton, K., Gershenson, D., Arze del Granado, J., Ishi, K., Kim, M., Kopp, E., and Rousset, M., 2019, "Fintech in Latin America and the Caribbean: Stocktaking," IMF Working Paper 19/71.

Cantú, C. and B. Ulloa, 2020, “The Dawn of fintech in Latin America: Landscape, Prospects, and Challenges," BIS Papers No 112.

Cambridge Centre for Alternative Finance, 2018a, "Business Access to Alternative Finance: A Deep Dive into Mexico and Chile".

Report." ,2018b, "Reaching New Heights: The $3^{\text {rd }}$ Americas Alternative Finance Industry ,2020, “The Global Alternative Finance Market Benchmarking Report”.

Cambridge Centre for Alternative Finance and the World Bank, 2019, "Regulating Alternative Finance: Results from A Global Regulator Survey”.

Cardim De Carvalho, F., De Paula, L.F., and Williams, J., 2012, "Banking in Latin America," in Berger, A., Molyneux, P., and Wilson, J. (eds.) The Oxford Handbook of Banking, January 2012.

Central Bank of Brazil, 2018, "Report on Financial Citizenship"

Claessens, S., Frost, J., Turner, G., and Zhu, F., 2018, "Fintech Credit Markets Around the World: Size, Drivers and Policy Issues,” BIS Quarterly Review September, 2018. 
Chortareas, G., Garza-Garcia, J., and Girardone, C., 2011, "Banking Sector Performance in Latin America: Market Power Versus Efficiency," Review of Development Economics 15(2), pp.30725.

Deloitte (2018), "Recently Enacted General Provisions Applicable to Financial Technology Institutions and Other Secondary Provisions Applicable Thereto", Deloitte Legal Alert 08/2018.

Demirgüç-Kunt, Asli, Leora Klapper, Dorothe Singer, Saniya Ansar, and Jake Hess (2018), "The Global Findex Database 2017: Measuring Financial Inclusion and the Fintech Revolution,” World Bank.

Demirgüç-Kunt, Asli, Luc Laeven, and Ross Levine 2004, "Regulations, Market Structure, Institutions, and the Cost of Financial Intermediation "Journal of Money, Credit and Banking 36(3), pp. 593-622

Endeavor Mexico, 2019, “Fintech Thermometer: The Challenges of Regulation.” Available at: https:/www.endeavor.org.mx/publicaciones/

Enoch, C., Bossu., W., Caceres, C., and Singh, D. (eds.), 2017, "Financial Integration in Latin America: A New Strategy for a New Normal,” International Monetary Fund.

Finnovista, 2016, "Fintech Radar Mexico.” Available at:

https://www.finnovista.com/radar/mexico-se-convierte-en-el-mayor-mercado-fintech-deamerica-latina/

, 2017, “Fintech Radar Mexico". Available at:

https://www.finnovista.com/en/radar/el-ecosistema-fintech-de-mexico-crece-un-50-en-menosde-un-ano/ , 2018, "Fintech Radar Mexico". Available at: https://www.finnovista.com/en/radar/mexico-exceeds-the-barrier-of-300-fintech-startups/ , 2019, "Fintech Radar Mexico". Available at: https:/www.finnovista.com/en/radar/el-ecosistema-fintech-mexicano-recupera-el-liderazgo-enamerica-latina-y-se-acerca-a-la-barrera-de-las-400-startups/ ,2020, "Fintech Radar Mexico". Available at: https://www.finnovista.com/en/radar/the-number-of-fintech-startups-in-mexico-grows-14-inone-year-to-441/

Herman, A. \& Klemm, A., 2017, “Financial Deepening in Mexico”, IMF working paper 17/19. 
International Finance, 2019, "Mexican fintechs are daring to take risks which the banks didn't", International Finance Magazine November - December 2019 Issue. Available at:

https://internationalfinance.com/mexican-fintechs-are-daring-take-risks-which-the-banks-didnt/

Ernst \& Young, 2018, “What lessons can we learn from FinTech adoption in Brazil?" available from https:/www.ey.com/en gl/financial-services-emeia/lessons-to-be-learned-from-fintechadoption-in-brazil

Frost, J., Gambacorta, L., Huang, Y., Shin, H. S., and Zbinden, P., 2019, "BigTech and the Changing Structure of Financial Intermediation” BIS Working Paper 779

Garber, G. and Nakane, M., 2015, "The Break of Brand Exclusivity in Brazilian Credit Card Acquiring: effects and markup-cost decomposition in a price dispersion setting", Central Bank of Brazil Working Paper 390

Gelos, G, 2006, “Banking Spreads in Latin America,” IMF Working Paper 06/44, International Monetary Fund.

Ho, T. and Saunders, A., 1981, "The Determinants of Bank Interest Margins: Theory and Empirical Evidence," Journal of Financial and Quantitative Analysis 16(4), pp. 581-600.

Igan, D., Martinez Peria, M. S., Pierri, N., and Presbitero, A., 2020, "When They Go Low, We Go High? Bank Market Power and Interest Rates”, IMF Working Paper.

Inter-American Development Bank, 2017, "Fintech Latin America: Innovations you may not Know Were from Latin America and the Caribbean" ,2018, "Fintech Latin America 2018: Growth and Consolidation"

International Monetary Fund, 2018, "Brazil: Financial System Stability Assessment”

International Monetary Fund -World Bank, 2016, "Mexico: Financial System Stability Assessment (FSAP)", IMF Country Report No. 16/361.

Mansilla-Fernández, J. M., 2017, "Numbers" in Fintech and Banking. Friends or Foes? by European Economy - Banks, Regulation, and the Real Sector 2017.2 (www.europeaneconomy.eu)

Martinez Peria, M. and Mody, A., 2004, "How Foreign Participation and Market Concentration Impact Bank Spreads," Journal of Money, Credit and Banking 36(3), pp. 511-37. 
McKinsey \& Company, 2019, "Brazil Digital Report”

Navaretti, B., Calzolari, and Pozzolo, 2017, “FinTech and Banks: Friends or Foes?”

Neary, J.P., 2007, “Cross-Border Mergers as Instruments of Comparative Advantage,” Review of Economic Studies 74(4), pp. 1229-57.

Nocke, V and Yeaple, S., 2007, "Cross-Border Mergers and Acquisitions vs. Greenfield Foreign Direct Investment: the Role of Firm Heterogeneity," Journal of International Economics Vol.72, pp. 336-65.

Shaffer, S and Spierdijk, L., 2020, "Measuring Multi-product Banks' Market Power using the Lerner Index,” Journal of Banking and Finnace Vol.117, pp. 1-16.

Valente, Augusto, and Murteira, "Differentiated Impact of Spread Determinants by Personal Loan Category: Evidence from the Brazilian Banking Sector”, CeBER Working Paper No. 12

Williams, B., 2007, "Factors Determining Net Interest Margins in Australia: Domestic and Foreign Banks," Finance Markets Institutions \& Instruments 16(3), August 2007.

World Bank, 2016, “Technical Note: SME Finance”, Mexico: Financial Sector Assessment Program.

Yildirim, H.S. and Philippatos, G.C., "Restructuring, Consolidation and Competition in Latin American Banking Markets," Journal of Banking \& Finance 31(3), March 2007, pp. 629-39. 


\section{Table 1. Summary Statistics}

\begin{tabular}{|c|c|c|c|c|}
\hline Variable & Source & Observations & Mean & S.D. \\
\hline Net interest margin & $\begin{array}{l}\text { Fitch Connect and } \\
\text { authors' calculations }\end{array}$ & 8118 & 6.5 & 5.71 \\
\hline Net fees & $\begin{array}{l}\text { Fitch Connect and } \\
\text { authors' calculations }\end{array}$ & 7690 & 1.86 & 2.17 \\
\hline Liquid assets & $\begin{array}{l}\text { Fitch Connect and } \\
\text { authors' calculations }\end{array}$ & 8867 & 24.93 & 19.37 \\
\hline Operating cost & $\begin{array}{l}\text { Fitch Connect and } \\
\text { authors' calculations }\end{array}$ & 8127 & 8.23 & 6.5 \\
\hline Total equity & $\begin{array}{l}\text { Fitch Connect and } \\
\text { authors' calculations }\end{array}$ & 8993 & 17.94 & 16.28 \\
\hline Non-performing loans & $\begin{array}{l}\text { Fitch Connect and } \\
\text { authors' calculations }\end{array}$ & 6110 & 7.09 & 10.05 \\
\hline Market share & $\begin{array}{l}\text { Fitch Connect and } \\
\text { authors' calculations }\end{array}$ & 8778 & 2.87 & 6.45 \\
\hline Foreign share & $\begin{array}{l}\text { Fitch Connect and } \\
\text { authors' calculations }\end{array}$ & 9132 & 24.68 & 15.48 \\
\hline $\mathrm{HHI}$ & $\begin{array}{l}\text { Fitch Connect and } \\
\text { authors' calculations }\end{array}$ & 9140 & 11.86 & 6.86 \\
\hline 3-bank concentration & $\begin{array}{l}\text { Fitch Connect and } \\
\text { authors' calculations }\end{array}$ & 9140 & 48.7 & 11.49 \\
\hline Gross loans to GDP & $\begin{array}{l}\text { Fitch Connect and } \\
\text { authors' calculations }\end{array}$ & 9140 & 32.14 & 17.66 \\
\hline Real GDP growth & IMF's WEO database & 9140 & 2.99 & 3.64 \\
\hline Inflation & IMF's WEO database & 8447 & 43.22 & 258.82 \\
\hline Real interest rate & $\begin{array}{l}\text { IMF's IFS database and } \\
\text { authors' calculations }\end{array}$ & 7752 & 54.49 & 452.98 \\
\hline EMBI spreads & $\begin{array}{l}\text { Thomson Reuters } \\
\text { Datastream }\end{array}$ & 7759 & 6.02 & 0.84 \\
\hline $\begin{array}{l}\text { Financial markets access } \\
\text { index }\end{array}$ & $\begin{array}{l}\text { IMF's Financial } \\
\text { Development Index }\end{array}$ & 8823 & 0.42 & 0.2 \\
\hline Lerner index & $\begin{array}{l}\text { Fitch Connect and Igan et } \\
\text { al. (2020) }\end{array}$ & 6039 & 0.36 & 0.23 \\
\hline
\end{tabular}


Table 2. Baseline Regression Results

\begin{tabular}{|c|c|c|c|c|}
\hline NIM & $(1)$ & $(2)$ & (3) & (4) \\
\hline Liquid Assets & $\begin{array}{c}-0.0229 * * * \\
(0.00728)\end{array}$ & $\begin{array}{c}-0.0226 * * * \\
(0.00721)\end{array}$ & $\begin{array}{c}-0.0229 * * * \\
(0.00729)\end{array}$ & $\begin{array}{c}-0.0229 * * * \\
(0.00728)\end{array}$ \\
\hline Net Fees & $\begin{array}{c}-0.212^{* *} \\
(0.0983)\end{array}$ & $\begin{array}{c}-0.209 * * \\
(0.0981)\end{array}$ & $\begin{array}{c}-0.212^{* *} \\
(0.0982)\end{array}$ & $\begin{array}{c}-0.213^{* *} \\
(0.0980)\end{array}$ \\
\hline Operating Costs & $\begin{array}{c}0.680 * * * \\
(0.0422)\end{array}$ & $\begin{array}{c}0.680 * * * \\
(0.0422)\end{array}$ & $\begin{array}{c}0.681^{* * * *} \\
(0.0422)\end{array}$ & $\begin{array}{c}0.682^{* * *} \\
(0.0421)\end{array}$ \\
\hline NPL & $\begin{array}{c}-0.0517 * * * \\
(0.0150)\end{array}$ & $\begin{array}{c}-0.0523^{* * *} \\
(0.0149)\end{array}$ & $\begin{array}{c}-0.0522^{* * *} \\
(0.0150)\end{array}$ & $\begin{array}{c}-0.0532^{* * *} \\
(0.0150)\end{array}$ \\
\hline Equity & $\begin{array}{c}0.0427^{* * *} \\
(0.00949)\end{array}$ & $\begin{array}{c}0.0420 * * * \\
(0.00941)\end{array}$ & $\begin{array}{c}0.0427^{* * *} \\
(0.00948)\end{array}$ & $\begin{array}{r}0.0427^{* * *} \\
(0.00948)\end{array}$ \\
\hline Market Share & $\begin{array}{l}-0.0103 \\
(0.0168)\end{array}$ & $\begin{array}{c}-0.0119 \\
(0.0164)\end{array}$ & $\begin{array}{c}-0.0101 \\
(0.0168)\end{array}$ & $\begin{array}{c}-0.0105 \\
(0.0168)\end{array}$ \\
\hline Foreign Dummy & $\begin{array}{c}-1.074 * * * \\
(0.267)\end{array}$ & $\begin{array}{c}-1.116^{* * *} \\
(0.263)\end{array}$ & $\begin{array}{c}-1.073^{* * *} \\
(0.267)\end{array}$ & $\begin{array}{c}-1.078^{* * *} \\
(0.266)\end{array}$ \\
\hline Foreign Dummy x Market Share & $\begin{array}{c}0.128 * * * \\
(0.0338)\end{array}$ & $\begin{array}{c}0.128 * * * \\
(0.0340)\end{array}$ & $\begin{array}{c}0.128 * * * \\
(0.0338)\end{array}$ & $\begin{array}{c}0.127 * * * \\
(0.0336)\end{array}$ \\
\hline Public Dummy & $\begin{array}{l}-0.448 \\
(0.328)\end{array}$ & $\begin{array}{l}-0.497 \\
(0.328)\end{array}$ & $\begin{array}{c}-0.443 \\
(0.328)\end{array}$ & $\begin{array}{c}-0.435 \\
(0.329)\end{array}$ \\
\hline Real Growth & $\begin{array}{c}0.173^{* * *} \\
(0.0378)\end{array}$ & $\begin{array}{c}0.188 * * * \\
(0.0376)\end{array}$ & $\begin{array}{c}0.172 * * * \\
(0.0376)\end{array}$ & $\begin{array}{c}0.171 * * * \\
(0.0377)\end{array}$ \\
\hline Inflation & $\begin{array}{c}-0.0240 \\
(0.0197)\end{array}$ & $\begin{array}{l}-0.0176 \\
(0.0195)\end{array}$ & $\begin{array}{l}-0.0243 \\
(0.0197)\end{array}$ & $\begin{array}{l}-0.0249 \\
(0.0196)\end{array}$ \\
\hline Total Loans/GDP & $\begin{array}{c}-0.0269 * * \\
(0.0120)\end{array}$ & $\begin{array}{c}-0.0419 * * * \\
(0.0120)\end{array}$ & $\begin{array}{c}-0.0269 * * \\
(0.0120)\end{array}$ & $\begin{array}{c}-0.0263^{* *} \\
(0.0120)\end{array}$ \\
\hline Real Interest Rate & $\begin{array}{c}0.0750 * * * \\
(0.0186)\end{array}$ & $\begin{array}{c}0.0836 * * * \\
(0.0183)\end{array}$ & $\begin{array}{c}0.0746 * * * \\
(0.0186)\end{array}$ & $\begin{array}{c}0.0747^{* * *} \\
(0.0186)\end{array}$ \\
\hline EMBI Spread & $\begin{array}{c}-0.488^{* *} \\
(0.209)\end{array}$ & $\begin{array}{c}-0.547^{* * *} \\
(0.209)\end{array}$ & $\begin{array}{c}-0.486^{* *} \\
(0.209)\end{array}$ & $\begin{array}{c}-0.473^{* *} \\
(0.209)\end{array}$ \\
\hline Foreign Market Share & $\begin{array}{l}0.00798 \\
(0.0132)\end{array}$ & $\begin{array}{l}0.00821 \\
(0.0130)\end{array}$ & $\begin{array}{l}0.00806 \\
(0.0132)\end{array}$ & $\begin{array}{l}0.00807 \\
(0.0132)\end{array}$ \\
\hline Financial Market Access Index & $\begin{array}{l}-0.913 \\
(0.967)\end{array}$ & $\begin{array}{l}-1.034 \\
(0.957)\end{array}$ & $\begin{array}{l}-0.900 \\
(0.972)\end{array}$ & $\begin{array}{l}-0.950 \\
(0.966)\end{array}$ \\
\hline $\mathrm{HHI}$ & $\begin{array}{l}0.149 * * \\
(0.0577)\end{array}$ & & $\begin{array}{l}0.148 * * \\
(0.0578)\end{array}$ & $\begin{array}{l}0.147^{* *} \\
(0.0578)\end{array}$ \\
\hline 3-Bank Concentration & & $\begin{array}{c}0.101^{* * *} \\
(0.0186)\end{array}$ & & \\
\hline M\&A Dummy & & & $\begin{array}{c}0.285 \\
(0.665)\end{array}$ & \\
\hline Foreign M\&A Dummy & & & & $\begin{array}{c}1.522 * * \\
(0.721)\end{array}$ \\
\hline Constants & $\begin{array}{c}3.859 * * \\
(1.948)\end{array}$ & $\begin{array}{c}1.561 \\
(1.999)\end{array}$ & $\begin{array}{c}3.851 * * \\
(1.950)\end{array}$ & $\begin{array}{c}3.827^{* *} \\
(1.946)\end{array}$ \\
\hline Observations & 4,085 & 4,085 & 4,085 & 4,085 \\
\hline R-squared & 0.619 & 0.623 & 0.619 & 0.620 \\
\hline $\mathrm{F}$ & 20.09 & 21.33 & 19.67 & 19.79 \\
\hline Country, Year FE & Yes & Yes & Yes & Yes \\
\hline N_clust & 507 & 507 & 507 & 507 \\
\hline
\end{tabular}


Table 3. Baseline Regression Results: Structural Shifts After the GFC

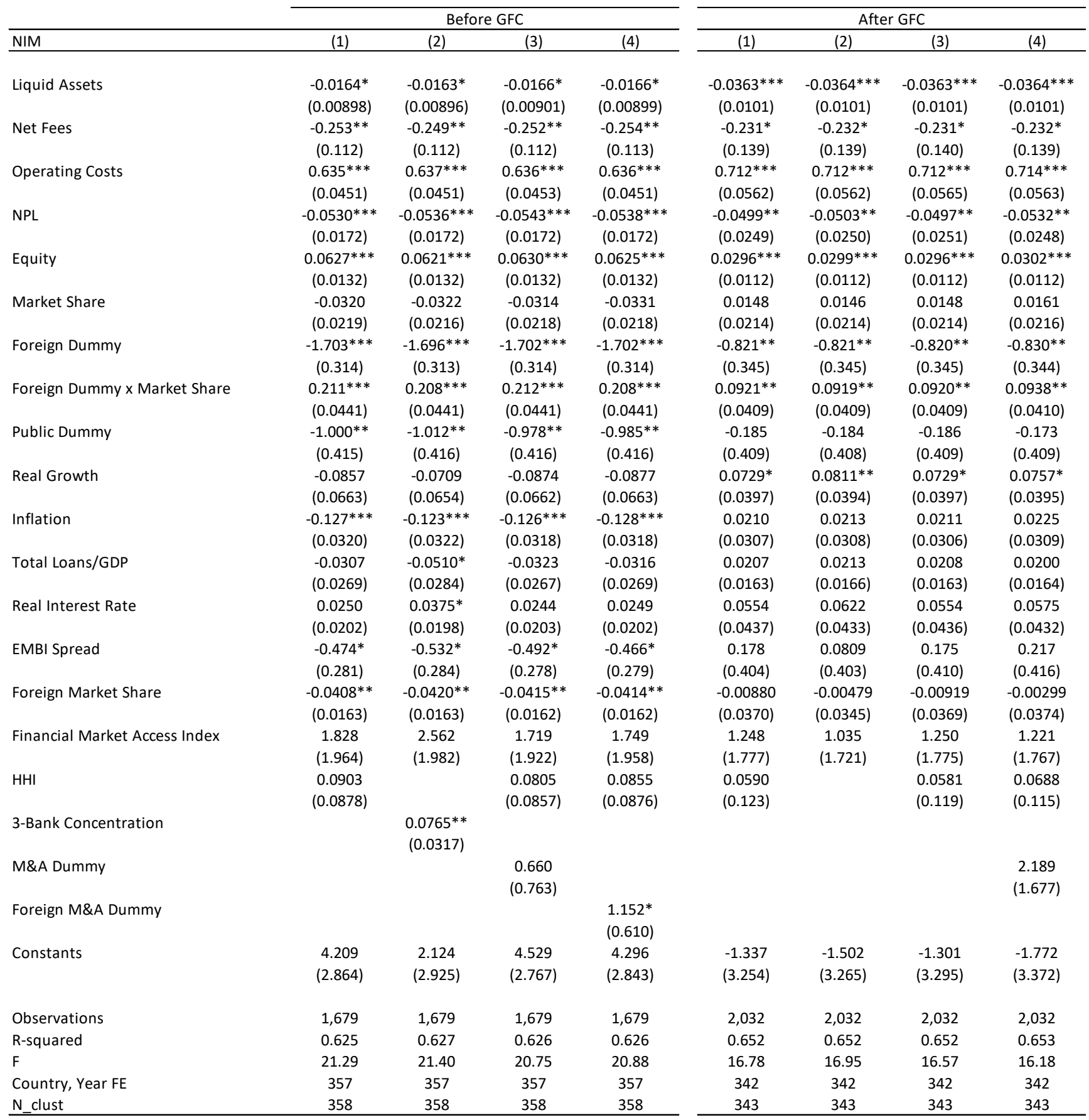

Robust standard errors in parentheses

*** $\mathrm{p}<0.01,{ }^{* *} \mathrm{p}<0.05, * \mathrm{p}<0.1$ 
Table 4. Robustness Check for Baseline Regressions

\begin{tabular}{|c|c|c|c|c|}
\hline Lerner Index & $(1)$ & $(2)$ & (3) & -4 \\
\hline Liquid Assets & $\begin{array}{c}-0.0000319 \\
(0.0000533)\end{array}$ & $\begin{array}{l}-0.0000352 \\
(0.0000533)\end{array}$ & $\begin{array}{l}-0.0000318 \\
(0.0000534)\end{array}$ & $\begin{array}{c}-0.0000314 \\
(0.0000535)\end{array}$ \\
\hline Net Fees & $\begin{array}{c}0.000688^{* *} \\
(0.000279)\end{array}$ & $\begin{array}{c}0.000667^{* *} \\
(0.000281)\end{array}$ & $\begin{array}{c}0.000687^{* *} \\
(0.000279)\end{array}$ & $\begin{array}{l}0.000684^{* *} \\
(0.000279)\end{array}$ \\
\hline Operating Costs & $\begin{array}{c}-0.000358^{* *} \\
(0.000142)\end{array}$ & $\begin{array}{c}-0.000356^{* *} \\
(0.000143)\end{array}$ & $\begin{array}{c}-0.000358^{* *} \\
(0.000142)\end{array}$ & $\begin{array}{c}-0.000362^{* * *} \\
(0.000142)\end{array}$ \\
\hline NPL & $\begin{array}{c}0.000155 \\
(0.000133)\end{array}$ & $\begin{array}{c}0.000155 \\
(0.000131)\end{array}$ & $\begin{array}{c}0.000157 \\
(0.000132)\end{array}$ & $\begin{array}{c}0.000161 \\
(0.000132)\end{array}$ \\
\hline Equity & $\begin{array}{c}3.67 \mathrm{e}-05 \\
(7.59 \mathrm{e}-05)\end{array}$ & $\begin{array}{c}0.0000404 \\
(0.0000760)\end{array}$ & $\begin{array}{c}0.0000366 \\
(0.0000759)\end{array}$ & $\begin{array}{c}0.0000369 \\
(0.0000759)\end{array}$ \\
\hline Market Share & $\begin{array}{l}-0.000249 \\
(0.000223)\end{array}$ & $\begin{array}{c}-0.000231 \\
(0.000222)\end{array}$ & $\begin{array}{c}-0.000249 \\
(0.000223)\end{array}$ & $\begin{array}{l}-0.000248 \\
(0.000224)\end{array}$ \\
\hline Foreign Dummy & $\begin{array}{l}-0.00290^{*} \\
(0.00169)\end{array}$ & $\begin{array}{l}-0.00285^{*} \\
(0.00168)\end{array}$ & $\begin{array}{l}-0.00290^{*} \\
(0.00169)\end{array}$ & $\begin{array}{l}-0.00287^{*} \\
(0.00170)\end{array}$ \\
\hline Foreign Dummy x Market Share & $\begin{array}{c}0.000531 \\
(0.000384)\end{array}$ & $\begin{array}{c}0.000539 \\
(0.000380)\end{array}$ & $\begin{array}{c}0.000531 \\
(0.000384)\end{array}$ & $\begin{array}{c}0.000537 \\
(0.000386)\end{array}$ \\
\hline Public Dummy & $\begin{array}{l}-0.00250 \\
(0.00178)\end{array}$ & $\begin{array}{c}-0.00245 \\
(0.00178)\end{array}$ & $\begin{array}{c}-0.00251 \\
(0.00178)\end{array}$ & $\begin{array}{c}-0.00256 \\
(0.00178)\end{array}$ \\
\hline Real Growth & $\begin{array}{c}-0.00537^{* * *} \\
(0.000619)\end{array}$ & $\begin{array}{c}-0.00535^{* * * *} \\
(0.000622)\end{array}$ & $\begin{array}{c}-0.00537 * * * \\
(0.000618)\end{array}$ & $\begin{array}{c}-0.00537^{* * *} \\
(0.000619)\end{array}$ \\
\hline Inflation & $\begin{array}{c}-0.00198^{* * * *} \\
(0.000240)\end{array}$ & $\begin{array}{c}-0.00195^{* * * *} \\
(0.000235)\end{array}$ & $\begin{array}{c}-0.00198^{* * * *} \\
(0.000240)\end{array}$ & $\begin{array}{c}-0.00198^{* * *} \\
(0.000240)\end{array}$ \\
\hline Total Loans/GDP & $\begin{array}{c}-0.000391^{* *} \\
(0.000180)\end{array}$ & $\begin{array}{c}-0.000363^{* *} \\
(0.000151)\end{array}$ & $\begin{array}{c}-0.000391 * * \\
(0.000179)\end{array}$ & $\begin{array}{c}-0.000394^{* *} \\
(0.000179)\end{array}$ \\
\hline Real Interest Rate & $\begin{array}{c}-0.00168^{* * * *} \\
(0.000214)\end{array}$ & $\begin{array}{c}-0.00170 * * * \\
(0.000216)\end{array}$ & $\begin{array}{c}-0.00168^{* * * *} \\
(0.000214)\end{array}$ & $\begin{array}{c}-0.00168 * * * \\
(0.000214)\end{array}$ \\
\hline EMBI Spread & $\begin{array}{c}-0.00643^{* *} \\
(0.00296)\end{array}$ & $\begin{array}{c}-0.00645^{* *} \\
(0.00287)\end{array}$ & $\begin{array}{c}-0.00644^{* *} \\
(0.00295)\end{array}$ & $\begin{array}{c}-0.00650^{* *} \\
(0.00295)\end{array}$ \\
\hline Foreign Market Share & $\begin{array}{l}-0.000420 \\
(0.000260)\end{array}$ & $\begin{array}{l}-0.000378 \\
(0.000268)\end{array}$ & $\begin{array}{l}-0.000421 \\
(0.000261)\end{array}$ & $\begin{array}{l}-0.000427 \\
(0.000262)\end{array}$ \\
\hline Public Banks' Market Share & $\begin{array}{c}0.00255^{* * * *} \\
(0.000538)\end{array}$ & $\begin{array}{c}0.00275^{* * * *} \\
(0.000641)\end{array}$ & $\begin{array}{l}0.00255^{* * *} \\
(0.000544)\end{array}$ & $\begin{array}{l}0.00254^{* * * *} \\
(0.000542)\end{array}$ \\
\hline Financial Market Access Index & $\begin{array}{c}0.190 * * * \\
(0.0123)\end{array}$ & $\begin{array}{c}0.192^{* * *} \\
(0.0119)\end{array}$ & $\begin{array}{c}0.190^{* * * *} \\
(0.0123)\end{array}$ & $\begin{array}{c}0.190^{* * * *} \\
(0.0123)\end{array}$ \\
\hline $\mathrm{HHI}$ & $\begin{array}{c}0.00197 \\
(0.00120)\end{array}$ & & $\begin{array}{l}0.00197^{*} \\
(0.00120)\end{array}$ & $\begin{array}{l}0.00199^{*} \\
(0.00120)\end{array}$ \\
\hline 3-Bank Concentration & & $\begin{array}{c}0.000425 \\
(0.000316)\end{array}$ & & \\
\hline M\&A Dummy & & & $\begin{array}{l}-0.000898 \\
(0.00549)\end{array}$ & \\
\hline Foreign M\&A Dummy & & & & $\begin{array}{r}-0.00853 \\
(0.0101)\end{array}$ \\
\hline Constants & $\begin{array}{l}0.00700 \\
(0.0275)\end{array}$ & $\begin{array}{r}-0.00353 \\
(0.0308)\end{array}$ & $\begin{array}{l}0.00714 \\
(0.0277)\end{array}$ & $\begin{array}{l}0.00788 \\
(0.0277)\end{array}$ \\
\hline Observations & 3,851 & 3,851 & 3,851 & 3,851 \\
\hline R-squared & 0.974 & 0.974 & 0.974 & 0.974 \\
\hline $\mathrm{F}$ & 11777 & 11958 & 11554 & 11596 \\
\hline N_clust & 483 & 483 & 483 & 483 \\
\hline
\end{tabular}


Table 5. Difference in Differences

\begin{tabular}{|c|c|c|}
\hline NIM & (1) & (2) \\
\hline \multirow[t]{2}{*}{ Liquid Assets } & -0.0112 & $-0.0139 * *$ \\
\hline & $(0.00684)$ & $(0.00656)$ \\
\hline \multirow[t]{2}{*}{ Net Fees } & $-0.244^{* *}$ & $-0.253^{* *}$ \\
\hline & $(0.100)$ & (0.101) \\
\hline \multirow[t]{2}{*}{ Operating Costs } & $0.694^{* * *}$ & $0.693 * * *$ \\
\hline & $(0.0429)$ & $(0.0434)$ \\
\hline \multirow[t]{2}{*}{ NPL } & $-0.0471 * * *$ & $-0.0468 * * *$ \\
\hline & $(0.0150)$ & $(0.0151)$ \\
\hline \multirow[t]{2}{*}{ Equity } & $0.0405^{* * *}$ & $0.0414 * * *$ \\
\hline & $(0.0106)$ & $(0.0105)$ \\
\hline \multirow[t]{2}{*}{ Market Share } & -0.0179 & -0.0225 \\
\hline & $(0.0173)$ & $(0.0181)$ \\
\hline \multirow[t]{2}{*}{ Foreign Dummy } & $-0.737^{* * *}$ & $-0.840 * * *$ \\
\hline & $(0.251)$ & $(0.253)$ \\
\hline \multirow[t]{2}{*}{ Public Dummy } & -0.281 & -0.345 \\
\hline & $(0.330)$ & $(0.329)$ \\
\hline \multirow[t]{2}{*}{ Real Growth } & $0.128 * * *$ & $0.113^{* * *}$ \\
\hline & $(0.0236)$ & $(0.0246)$ \\
\hline \multirow[t]{2}{*}{ Inflation } & $-0.0482 * * *$ & $-0.0591 * * *$ \\
\hline & $(0.0141)$ & $(0.0148)$ \\
\hline \multirow[t]{2}{*}{ Total Loans/GDP } & $-0.0217^{* * *}$ & $-0.0292 * * *$ \\
\hline & $(0.00804)$ & $(0.00804)$ \\
\hline \multirow[t]{2}{*}{ Real Interest Rate } & $0.0916^{* * *}$ & $0.0920 * * *$ \\
\hline & $(0.0180)$ & $(0.0187)$ \\
\hline \multirow[t]{2}{*}{ EMBI spread } & $-0.342 * *$ & $-0.419 * * *$ \\
\hline & $(0.143)$ & $(0.146)$ \\
\hline \multirow[t]{2}{*}{ Foreign Market Share } & $-0.0406 * * *$ & $-0.0532 * * *$ \\
\hline & (0.0109) & $(0.0107)$ \\
\hline \multirow[t]{2}{*}{ Financial Market Access Index } & $-3.309 * * *$ & $-1.399 * *$ \\
\hline & $(0.942)$ & $(0.705)$ \\
\hline \multirow[t]{2}{*}{$\mathrm{HHI}$} & $0.208 * * *$ & $0.220 * * *$ \\
\hline & $(0.0411)$ & $(0.0403)$ \\
\hline \multirow[t]{2}{*}{ Fintech Period Dummy } & $1.437^{* *}$ & $0.314^{*}$ \\
\hline & $(0.592)$ & $(0.184)$ \\
\hline \multirow[t]{2}{*}{ Fintech Country Dummy } & $2.343^{* * *}$ & \\
\hline & $(0.741)$ & \\
\hline \multirow[t]{2}{*}{ Fintech Period Dummy x Fintech Country Dummy } & $-1.194^{*}$ & \\
\hline & $(0.619)$ & \\
\hline \multirow[t]{2}{*}{ Fintech Intensity } & & 1.086 \\
\hline & & $(6.073)$ \\
\hline \multirow[t]{2}{*}{ Constant } & 2.171 & $4.649 * * *$ \\
\hline & $(1.595)$ & $(1.452)$ \\
\hline Observations & 4,085 & 4,085 \\
\hline R-squared & 0.579 & 0.575 \\
\hline N_clust & 507 & 507 \\
\hline
\end{tabular}

Robust standard errors in parentheses

*** $\mathrm{p}<0.01,{ }^{* *} \mathrm{p}<0.05, * \mathrm{p}<0.1$ 